\title{
Lower trophic levels and detrital biomass control the Bay of Biscay continental shelf food web: Implications for ecosystem management
}

\author{
G. Lassalle ${ }^{a, *}$, J. Lobry $^{\text {b }}$, F. Le Loc'h ${ }^{c}$, P. Bustamante ${ }^{a}$, G. Certain ${ }^{\text {a,d }}$, D. Delmas ${ }^{\text {e }}$, \\ C. Dupuy ${ }^{a}$, C. Hily ${ }^{f}$, C. Labry ${ }^{\text {e }}$, O. Le Pape ${ }^{g}$, E. Marquis ${ }^{\text {a,h }}$, P. Petitgas ${ }^{\text {i }}$, \\ C. Pusineri ${ }^{a, j}$, V. Ridoux ${ }^{a, k}$, J. Spitz $^{a}$, N. Niquil ${ }^{a}$
}

${ }^{a}$ Littoral Environnement et Sociétés, UMR 6250 CNRS-Université de La Rochelle, 2 rue Olympe de Gouges, 17042 La Rochelle, Cedex, France

${ }^{\mathrm{b}}$ Cemagref, Agricultural and Environmental Engineering Research Institute, UR EPBX, 50 avenue de Verdun, 33612 Cestas, Cedex, France

${ }^{c}$ IRD, UMR 212 Écosystèmes Marins Exploités, IRD-IFREMER-CNRS-Université Montpellier 2, Avenue Jean Monnet, BP 17134203 Sète, Cedex, France

${ }^{d}$ Institute of Marine Research, P.O. Box 6404, 9294 Tromsø, Norway

e IFREMER, Département Dynamique de l'Environnement Côtier, Laboratoire Pélagos, BP 70, 29280

Plouzané, France

' Laboratoire des sciences de l'Environnement MARin, CNRS UMR 6539, Institut Universitaire Européen de la Mer, Université Occidentale de Bretagne, 29280 Plouzané, France

${ }^{9}$ Université Européenne de Bretagne, UMR 985 Agrocampus Ouest, Inra Écologie et Santé des

Écosystèmes, Écologie halieutique, Agrocampus Ouest, 65 rue de St Brieuc, CS 84215, 35042 Rennes, France

${ }^{\mathrm{h}}$ Institute of Oceanography, National Taiwan University, No. 1, Section 4, Roosevelt Road, 10617

Taipei, Taiwan

' IFREMER, Département Écologie et Modèles pour l'Halieutique, rue de l'île d'Yeu, BP 21105, 44311

Nantes, France

j Office National de la Chasse et de la Faune Sauvage, Cellule Technique Océan Indien, PB 67, 97670 Coconi, Mayotte

${ }^{k}$ Centre de Recherche sur les Mammifères Marins, UMS 3419 CNRS-Université de La Rochelle, 17071 La Rochelle, France

*: Corresponding author : Tel.: +33 5465076 46; fax: +33 546507663 ; geraldine.lassalle@univ-Ir.fr

\begin{abstract}
:
The Bay of Biscay (North-East Atlantic) has long been subjected to intense direct and indirect human activities that lead to the excessive degradation and sometimes overexploitation of natural resources. Fisheries management is gradually moving away from single-species assessments to more holistic, multi-species approaches that better respond to the reality of ecosystem processes. Quantitative modelling methods such as Ecopath with Ecosim can be useful tools for planning, implementing and evaluating ecosystem-based fisheries management strategies. The aim of this study was therefore to model the energy fluxes within the food web of this highly pressured ecosystem and to extract practical information required in the diagnosis of ecosystem state/health. A well-described model comprising 30 living and two non-living compartments was successfully constructed with data of local origin, for the Bay of Biscay continental shelf. The same level of aggregation was applied to primary producers, mid-trophic-levels and top-predators boxes. The model was even more general as it encompassed the entire continuum of marine habitats, from benthic to pelagic domains. Output values for most ecosystem attributes indicated a relatively mature and stable ecosystem, with a large proportion of its energy flow originating from detritus. Ecological network analysis also provided evidence that bottom-up processes play a significant role in the population dynamics of upper-trophiclevels and in the global structuring of this marine ecosystem. Finally, a novel metric based on ecosystem production depicted an ecosystem not far from being overexploited. This finding being not entirely consistent over indicators, further analyses based on dynamic simulations are required.

Key words : Ecopath; aquatic communities; trophic structure; bottom-up control; multispecies fisheries; ecosystem management; North-East Atlantic, Bay of Biscay, continental shelf.
\end{abstract}

Key words : Ecopath; aquatic communities; trophic structure; bottom-up control; multispecies fisheries; ecosystem management; North-East Atlantic, Bay of Biscay, continental shelf. 


\section{Introduction}

Impacts of fisheries on target species have been abundantly described and reviewed, e.g. modifications of abundance, spawning potential, growth and maturation, age and size structure, sex ratio, genetics (Hall, 1999). However, the effect of fishing is not restricted to commercially exploited species but extends to entire ecosystems. In most cases, by targeting and reducing the abundance of high-value consumers, fisheries profoundly modify trophic networks and the flow of biomass (and energy) across the ecosystem, leading sometimes to trophic cascades (Heithaus et al., 2008) and ultimately to regime shifts (Daskalov et al., 2007). In addition, fishing practices can durably and substantially damage the living and nonliving environment of target and associated resources, e.g. poorly-selective fishing activities generate by-catch and discards and sometimes cause local anoxia (Diaz et al., 2008), benthic trawls and dredges cause physical changes to the seabed (Hall-Spencer et al., 2002), and lost fishing gear that preserves its catching abilities leads to temporary "ghost fishing" (Baeta et al., 2009). Consequently, in the last two decades, a consensus has emerged on the need to move from single species- to ecosystem-based fisheries management (EBFM). The goal is "to rebuild and sustain populations, species, biological communities and marine ecosystems at high levels of productivity and biological diversity so as not to jeopardize a wide range of goods and services from marine ecosystems while providing food, revenues and recreation for humans" (Browman et al., 2004).

Although the importance of an ecosystem approach is widely accepted, it remains difficult to put these principles into practice (Tallis et al., 2010). In data-rich situations, multispecies/ecosystem models are valuable tools that bring coherence to a large amount of data from a variety of sources (see Plagànyi (2007) for an exhaustive review). They can be useful to provide initially a holistic understanding of the structure and functioning of a particular aquatic system and then supply concrete elements for managing this exploited ecosystem. For 
example, they have been used to explore marine protected area (MPA) zoning options or to assist the implementation of EBFM through the identification of critical biological indicators and their corresponding threshold values (Tudela et al., 2005; Coll et al., 2008). Among ecosystem models, Ecopath with Ecosim (EwE) is a well-known and freely-available software package which attempts to represent all trophic groups, in a mass-balanced way (Polovina, 1984; Christensen and Pauly, 1992). The ecosystem is considered as a unit of biological organization, made up of all the organisms in a given area, interacting with the physical environment, so that a flow of energy leads to characteristic trophic structure and material cycles within the system (Odum, 1969). Through the development of new components and modules, EwE has become increasingly powerful in providing information on how a system is likely to respond to potential changes in fisheries management practices and, to a lesser extent, to environmental disturbances (Coll et al., 2007; Shannon et al., 2009). Some of the fundamental strengths of the approach are the achievement of a good trade-off in model structure between simplicity and complexity (i.e. parsimony principle; Fulton et al. (2003)) and the use of a common and rigorous analytical framework that make comparisons between various systems possible (Plagànyi and Butterworth, 2004).

At the western edge of the Eurasian continent, the Bay of Biscay, opening to the Eastern North Atlantic Ocean, supports a large number of anthropogenic activities including tourism and shellfish farming along the coasts and intensive fisheries for human consumption over the shelf and along the slopes (Lorance et al., 2009). Fishing activities in the Bay of Biscay involve several European countries and are characterised by the wide variety of fishing vessels, gears and techniques, the large number of landed species (more than a hundred) and the numerous habitats explored (Léauté, 1998). The major commercially exploited stocks are crustaceans, cephalopods and both pelagic and demersal fish, some of them showing signs of intensive exploitation (ICES, 2005b). For instance, since 2002, European anchovy recruitment 
112 has experienced a severe decline that raises growing concerns from the scientific community

113 and EU member states as to what would be the direct and indirect effects of alternative

114 harvest strategies of forage fish on other ecosystem components (ICES, 2010).

115 In this context of intense multi-species exploitation, a mass-balanced model of the Bay of

116 Biscay continental shelf food web would be of great interest to stakeholders and decision

117 makers to support the implementation of sustainable fisheries policies and the development of

118 ecosystem-based management in the area. Models already exist for different parts of the Bay

119 of Biscay continental shelf with special hydro-morphological characteristics, i.e. the "Grande

120 Vasière" (Le Loc'h, 2004), the Cantabrian Sea (Sanchez and Olaso, 2004). At a broader

121 spatial scale, including the totality of the two ICES sub-divisions VIIIa and b, two models

122 were constructed for the year 1970 and 1998 by Ainsworth et al. (2001). Little help was

123 provided by local researchers for those two previous models and as a consequence, most

124 biomass data in their initial input matrix were lacking or obtained from similar systems

125 (Sylvie Guénette, pers. comm.). Ainsworth et al. (2001) paid particular attention to fish

126 species that were divided, according to a length criterion, into 22 distinct functional groups.

127 These models recently served as a strong basis for a Master's thesis (Jimeno, 2010), in which

128 the "2007" situation was modelled. Previous models of the Bay of Biscay were lacking of

129 sufficient spatial coverage and amount of local data to be useful. The construction of a new

130 model was made possible by the two successive phases of the French coastal environmental

131 research program (PNEC 1999-2003 and 2004-2007) that both included a specific worksite on

132 the Bay of Biscay and that thus greatly contributed to fill the gaps that existed in the data

133 concerning this area. In the present work, a particular effort was made to combine local

134 information of the same quality, reliability and detail, on both the benthic and pelagic

135 communities, from primary producers to top-predators to better understand the structure,

136 organization and functioning of the Bay of Biscay continental shelf food web. Then, the 
137 keystone compartments according to the original definition provided by Power et al. (1996),

138 i.e. components whose effect is large, and disproportionately large relative to their abundance,

139 were determined. Finally, the ecosystem exploitation status was assessed using a set of

140 metrics, some being based on ecosystem production.

141

\section{2. Material and Methods}

$143 \quad 2.1$ Study area

144 The Bay of Biscay is a large gulf of the Atlantic Ocean located off the western coast of France

145 and the northern coast of Spain, between 48.5 and $43.5^{\circ} \mathrm{N}$ and 8 and $3{ }^{\circ} \mathrm{W}$ (Fig. 1). The

146 principal rivers in decreasing order of drainage area are: the Loire, Garonne-Dordogne

147 (Gironde complex), Adour, Vilaine and Charente rivers. The continental shelf reaches widths

148 of about $140 \mathrm{~km}$ off the coast of Brittany but narrows to less than $15 \mathrm{~km}$ off the Spanish

149 shore. The physical and hydrological features of the Bay of Biscay are of great complexity,

150 e.g. coastal upwelling, coastal run-off and river plumes, seasonal currents, eddies, internal

151 waves and tidal fronts (Planque et al., 2004). These abiotic processes greatly influence the

152 phytoplankton dynamics and as a consequence, the whole food-web composition, structure

153 and functioning (Varela, 1996).

154 The model was restricted to divisions VIIIa and $\mathrm{b}$ of the International Council for the

155 Exploration of the Sea (ICES; www.ices.dk). An ecosystem model has already been built for

156 the Cantabrian Sea, which exhibits particular hydro-morphological characteristics (ICES

157 division VIIIc) (Sanchez and Olaso, 2004). The deep offshore basin (ICES division VIIId)

158 was not sufficiently documented to be included into the modelling process. The study site in

159 the Bay of Biscay was limited to the middle-depth continental shelf, between the $30-\mathrm{m}$ and

$160150-\mathrm{m}$ isobaths, and its surface area was considered to be $102,585 \mathrm{~km}^{2}$. There has been long- 
161 term, consistent and regular monitoring of the benthic, demersal and pelagic biota in this

162 study area.

2.2 Trophic modelling approach

165 A mass-balance (neglecting year-to-year change in biomass, compared to flows) model of the

166 Bay of Biscay continental shelf was constructed using Ecopath with Ecosim 6 (Christensen

167 and Pauly, 1992; Christensen et al., 2008). The model combines biomass, production and

168 consumption estimates to quantify flows between the different elements of aquatic exploited

169 ecosystems at a specific point in time. The parameterisation of the Ecopath model is based on

170 satisfying two "master" equations. The first describes the production term for each

171 compartment (species or group of species with similar ecotrophic roles) included in the

172 system:

173 Production $=$ fishery catch + predation mortality + net migration + biomass accumulation +

174 other mortality.

175 "Other mortality" includes natural mortality factors such as mortality due to senescence,

176 diseases, etc. The second equation expresses the principle of conservation of matter within a

177 compartment:

178 Consumption $=$ production + respiration + unassimilated food.

179 The formal expressions of the above equations can be written as follows for a group $i$ and its

180 predator $j$ :

$181 B_{i} \times(P / B)_{i}=Y_{i}+\sum_{j}\left(B_{j} \times(Q / B)_{j} \times D C_{i j}\right)+E x_{i}+B_{a c c_{i}}+B_{i}\left(1-E E_{i}\right) \times(P / B)_{i}$

182 and

183

$B_{i} \times(Q / B)_{i}=B_{i} \times(P / B)_{i}+R_{i}+U_{i}$

184 where the main input parameters are biomass density $\left(B\right.$, here in $\left.\mathrm{kg} \mathrm{C} \cdot \mathrm{km}^{-2}\right)$, production rate

$185\left(P / B\right.$, year $\left.^{-1}\right)$, consumption rate $\left(Q / B\right.$, year $\left.^{-1}\right)$, proportion of $i$ in the $\operatorname{diet}$ of $j\left(D C_{i j} ; D C=\operatorname{diet}\right.$ 
186

187

composition), net migration rate $\left(E x\right.$, year $\left.^{-1}\right)$, biomass accumulation $\left(B a c c\right.$, year $\left.^{-1}\right)$, total catch $\left(Y ; \mathrm{kg} \mathrm{C} \cdot \mathrm{km}^{-2}\right)$, respiration $\left(R ; \mathrm{kg} \mathrm{C} \cdot \mathrm{km}^{-2} \cdot \mathrm{year}^{-1}\right)$, unassimilated food rate $(U)$ and ecotrophic efficiency $(E E)$.

Biomass, $Q / B$ and $P / B$ values of multi-species compartments were determined by the weighted average of the relative abundance of each species. There are as many linear equations as groups in the system, so if one of the parameters is unknown for a group, the model computes it by solving the set of linear equations. In particular, $E E$, which corresponds to the fraction of the production of each group that is used in the food web, is difficult to measure. Hence, it was estimated by the model for most of the groups. The "manual" massbalanced procedure that includes two major levels of verification was used. First, for those groups with $E E>1$, the model was modified by adjusting their initial input parameters and the predation intensity exerted by predators on them (slight and gradual increase or decrease in values, within the interval of confidence of the parameter). For this parameter, a value greater than one indicated a demand on the compartment that was too high to be sustainable within the food web. Secondly, the same procedure was applied to the gross food conversion efficiency $(G E)$ estimates, also called $P / Q$ ratio, which must be in the physiologically realistic range of 0.1-0.3 for most consumers and generally higher for small organisms. $E E$ for a detritus group is defined as the ratio between what flows out of that group and what flows into it. Theoretically, under steady-state assumption, this ratio should be equal to one.

The Ecopath model was validated using the pre-balance (PREBAL) diagnostics (Link, 2010) to ensure that any potential and major problems are captured before network outputs are used to address research or management questions. PREBAL provides a set of guidelines presented as a form of "checklist". Diagnostic tests allow evaluation of the cohesiveness of the data despite the natural discrepancies that occur when using myriad data sources measured across varying scales. In brief, each functional group was plotted along the x-axis in order of 
211 decreasing trophic level to allow easy visualization of trophic relationships. Byron et al.

212 (2011) summarized the PREBAL analysis into five simple ecological and physiological

213 "rules" that should be met.

2152.3 Defining the model compartments

216 Functional groups were defined following three criteria: the similarities between the species

217 in terms of size and food preferences, the amount of ecological data available to determine 218 precise parameters and diet compositions and the main research questions to which the model 219 should respond. On this basis, 32 trophic groups were retained (Table 1), two of which were 220 seabirds, five marine mammals, nine fish, eight invertebrates, three zooplankton, two primary 221 producers, one bacteria, discards from commercial fisheries and detritus corresponding to 222 allochthonous imports into the web and autochthonous internal cycling within the web. Data collections for plankton to top-predators (marine birds and small cetaceans) cover a period

224 long enough for sufficient data to be available, but short enough for massive changes in 225 biomass not to have occurred. They encompassed different seasons and years, starting in 1994 226 and ending in 2005. The European anchovy Engraulis encrasicolus has been affected by a 227 below average recruitment since 2002, which led to the closure of the fishery in the area from 228 June 2006 to December 2009 (ICES, 2010). The model presented in this study corresponded 229 to a typical year between 1994 and 2005, before the collapse of the anchovy fishery.

230 Biomasses, diets and species compositions were averaged across seasons.

2322.4 Initial input parameters and diet compositions

2.4.1 Marine mammals and seabirds

234 Birds were counted visually and identified to species level by aerial surveys on a monthly

235 basis from October 2001 to March 2002, in August 2002, in June 2003 and May 2004 
(ROMER and ATLANCET surveys). The Bay of Biscay is heavily used as a migration route and as a wintering area for marine birds, so there is a great seasonal variation in their abundance. As this long-distance migratory pattern was included through an annual biomass estimate, imports were not added to their diets. The four most abundant seabird taxa were northern gannets Sula bassana, large gulls (i.e. herring gulls Larus argentatus, lesser blackbacked gulls Larus fuscus, great black-backed gulls Larus maritimus and yellow-legged gull Larus michahellis), kittiwakes Rissa tridactyla and auks (i.e. common murres Uria aalge, razorbills Alca torda and Atlantic puffins Fratercula arctica) (Certain and Bretagnolle, 2008)

244 (Table 1). Based on Hunt et al. (2005), the mean body mass for these taxa was set to 3.2, 1.1, 0.4 and $0.9 \mathrm{~kg}$ respectively. They were grouped in two categories according to feeding strategies: "surface feeders" for gulls and kittiwakes and "plunge and pursuit divers" for gannets and auks. Wet weights were converted into dry weights and carbon contents based on two conversion factors, i.e. 0.3 and 0.4 respectively. These values were derived from expert's knowledge on the basis of the carbon to wet mass ratio of 0.1 used by Heymans and Baird (2000).

Their diet regime was assumed to be composed mostly of energy-rich pelagic species and 252 large zooplankton crustaceans (Hunt et al., 2005; Certain et al., 2011). Some marine birds are also well-known to feed largely on fisheries discards (Arcos, 2001). This artificial low-quality

254 food source has been shown to be detrimental on a long-term basis for gannets (Grémillet et al., 2008) (Table 2).

256 Daily ration for wild piscivorous birds $\left(R_{c}\right)$ in $\mathrm{g} \cdot \mathrm{day}^{-1}$ was calculated according to the 257 following empirical equation (Nilsson and Nilsson, 1976):

$$
\log \left(R_{c}\right)=-0.293+0.85 \times \log (W)
$$

259 where $W$ is the body mass of birds expressed in $\mathrm{g}$. This value was then multiplied by 365 days 260 and divided by the mean weight of the taxon to provide annual $Q / B$ ratio. 
The $P / B$ ratio for the two functional groups was based on estimates published in Nelson

262 (1979).

263 Abundance for the small cetacean community (porpoises and dolphins excluding whales) was

264 derived from the combination of results from (i) the SCANS-II project focusing on small 265 cetaceans in the European Atlantic and the North Sea and carried out in July 2005 by ships 266 and aircraft, (ii) the estimated small delphinid abundance in the Bay of Biscay based on 267 repeated extensive aerial surveys (ROMER and ATLANCET campaigns) in different seasons and years (2001-2004) across the Bay of Biscay continental shelf (Certain et al., 2008), and

(iii) the monitoring of marine mammals in the same area based on stranding and spring shipboard observations performed during PELGAS IFREMER cruises (Certain et al. (2011); 271 authors' unpublished data). The five most common species were separated in the model: the 272 common dolphin Delphinus delphis, the striped dolphin Stenella coeruleoalba, the bottlenose dolphin Tursiops truncatus, the long-finned pilot whale Globicephala melas and the harbour porpoise Phocoena phocoena (Table 1). Following the method developed by Trites and Pauly (1998), mean body weight was calculated for each species according to its maximum body

276 length. A conversion factor of 0.1 for wet weight to carbon content was used (Bradford277 Grieve et al., 2003).

278 Diet compositions were obtained from stomach content analysis of stranded animals found 279 along the North-East Atlantic French coast (Spitz et al., 2006a; Spitz et al., 2006b; Meynier et 280 al., 2008). Some cetacean species forage both on the shelf and on the oceanic domains of the 281 Bay of Biscay. Consequently, the proportion of oceanic prey in their diet was considered as 282 imports (Table 2).

283 Consumption can be estimated from energy requirements, prey energy densities and prey 284 compositions by percent mass. The daily energy requirement or field metabolic rate $(F M R)$ in 
$285 \mathrm{~kJ} \cdot \mathrm{day}^{-1}$ is related to mean body mass ( $W$ in $\mathrm{kg}$ ) according to the model developed by Boyd 286 (2002), the coefficient used was the one proposed by the author for marine mammals alone:

$287 \quad F M R=2629 \times W^{0.524}$

288 Daily consumption $\left(R_{c}\right)$ in $\mathrm{kg} \cdot \mathrm{day}^{-1}$ was calculated by converting energy requirements to food 289 biomass and adjusting by a factor of assimilation efficiency:

$290 \quad R_{c}=F M R /\left(0.8 \times \sum\left(P_{i} \times E D_{i}\right)\right)$

291 where $P_{i}$ was the proportion by mass of prey species $i$ in the diet and $E D_{i}$, the energy density 292 of prey $i\left(\mathrm{~kJ}^{\mathrm{k}} \mathrm{kg}^{-1}\right.$; Spitz et al. (2010)). Assimilation efficiency was typically estimated at 0.8 293 (Leaper and Lavigne, 2007). This value was then multiplied by 365 days and divided by the 294 mean weight of the taxon to provide annual $Q / B$ ratio.

295 Values of $P / B$ were taken from Christensen et al. (2009); they varied from 0.03 for baleen 296 whales to 0.08 for dolphins and porpoises.

\subsubsection{Fish groups}

299 Stocks of the common sole Solea solea, the European hake Merluccius merluccius, two

300 European anglerfish Lophius budegassa and L. piscatorius and the megrim Lepidorhombus 301 whiffiagonis were assessed from ICES/ACFM advice report (ICES, 2004). The biomass of 302 most other benthic and demersal fish species was estimated from bottom-trawl surveys conducted annually in autumn in the Bay of Biscay (EVHOE IFREMER cruises). Data were averaged over six years, between 1998 and 2003 and then multiplied by four to take into account the mean bottom-trawl capture efficiency below 0.3 (Trenkel and Skaug, 2005). The capture efficiency represents the proportion of individuals in the trawl path being retained by

307 the gear. Wet body weights were converted to dry weights and then to carbon contents using 308 conversion factors of 0.2 and 0.4 respectively (Brey et al., 2010). The biomass of most pelagic 309 fish species was estimated using data from acoustic surveys conducted each spring in the Bay 
310 of Biscay (PELGAS IFREMER cruises). Data were averaged over three years, between 2000

311 and 2003. The distribution range of the horse mackerel Trachurus trachurus was not fully

312 encompassed by IFREMER surveys, which resulted in an underestimation of the total

313 biomass. Thus, an ecotrophic efficiency of 0.95 was preferentially entered in the input

314 parameters for this commercially exploited species and the biomass was left to be estimated

315 by the model. Wet body weights were first converted to dry weights with a conversion factor

316 of 0.14 and finally to carbon contents using a conversion factor of 0.45 (Jorgensen et al.,

317 1991) (Table 1).

318 The $Q / B$ ratio was determined using Fishbase (Froese and Pauly (2000); www.fishbase.org).

319 For each species, $Q / B$ was estimated from the empirical relationship proposed by Palomares

320 and Pauly (1998):

$321 \log (Q / B)=7.964-0.204 \times \log \left(W_{\infty}\right)-1.965 \times T^{\prime}+0.083 \times A+0.532 \times h+0.398 \times$

$322 d(6)$

323 where $W_{\infty}$ was the asymptotic weight, $T$ ' was the mean environmental temperature expressed

324 as $1000 /\left(\mathrm{T}\left({ }^{\circ} \mathrm{C}\right)+273.15\right), A$ was the aspect ratio of the caudal fin, $h$ and $d$ were dummy

325 variables indicating herbivores $(h=1, d=0)$, detritivores $(h=0, d=1)$ and carnivores $(h=0, d=0)$.

326 Under steady-state conditions, the $P / B$ ratio is equal to instantaneous coefficient of total

327 mortality (Z) (Allen, 1971):

$328 \quad Z=M+F \quad(7)$

329 with $M$ being natural and $F$ fishing mortality. $M$ was calculated using the Fishbase life-history

330 tool from Pauly's (1980) empirical equation:

$M=K^{0.65} \times L_{\infty}^{-0.279} \times T^{0.463}$

332 where $K$ was the curvature parameter of the von Bertalanffy growth function (VBGF), $L_{\infty}$ the

333 asymptotic length and $T$ the mean environmental temperature in ${ }^{\circ} \mathrm{C}$. If no estimate of $K$ was

334 available, $M$ was calculated from the preliminary empirical relationship: 
336 Parameters of the VBGF were taken from publications, calculated from survey data or, most 337 often, found on Fishbase.

338 A mean temperature of $11^{\circ} \mathrm{C}$ for benthic and demersal fish and $14^{\circ} \mathrm{C}$ for pelagic fish were

339 assumed, considering that former species live on or near the sea bottom. Fishing mortality

340 was set to zero for non-commercial species such as the European sprat Sprattus Sprattus.

341 Whenever possible, fishing mortality was taken directly from ICES reports, otherwise, it was

342 estimated from the same sources by dividing catches by biomasses. For the horse mackerel

343 Trachurus trachurus, the instantaneous rate of total mortality $(Z)$ was estimated using the

344 Hoenig (1983) empirical equation based on a maximum observed age $\left(t_{\max }\right)$ of 15 years:

$345 \operatorname{Ln}(Z)=1.44-0.984 \times \ln \left(t_{-} \max \right)$

346 For demersal and benthic fish species, knowledge of their diet came from the literature and

347 Fishbase, as well as stomach contents (Le Loc'h, 2004) and carbon and nitrogen stable

348 isotopic analysis performed on specimens captured on a large sedimentary muddy bank

349 known as the "Grande Vasière" and on the external margin of the continental shelf (Le Loc'h

350 et al., 2008) (Table 2). They were consequently grouped into four categories: "Benthivorous

351 demersal fish" comprised 24 species, including the common sole Solea solea;

352 "Suprabenthivorous demersal fish" included eight species such as the blue whiting

353 Micromesistius poutassou and small European hakes $(<10 \mathrm{~cm})$ Merluccius merluccius;

354 "Piscivorous and benthivorous demersal fish" contained, among 41 other species, the

355 European conger Conger conger, the pouting Trisopterus luscus and the small-spotted

356 catshark Scyliorhinus canicula; "Piscivorous demersal fish" included large specimens of the

357 European hake which have a diet consisting of both demersal and pelagic fish (the full list of 358 species is given in the first supplementary material). 
359 Based exclusively on experts' knowledge, the pelagic species were divided into five groups,

360 each representing a well-known, valuable and strategic species. Three thoroughly-monitored

361 clupeid species, the European anchovy Engraulis encrasicolus, the European sprat Sprattus

362 sprattus and the European pilchard Sardina pilchardus, were taken into account. The first two

363 feed exclusively on mesozooplankton $(200<$ size $<2000 \mu \mathrm{m})$ (Whitehead, 1985). However,

364 an ontogenetic dietary shift to smaller prey represented by microzooplankton $(<200 \mu \mathrm{m})$ and

365 large phytoplanktonic cells $(>3 \mu \mathrm{m})$ was apparent in approximately one year-old pilchards

366 (individuals $<18 \mathrm{~cm}$ ) (Bode et al., 2004). Percentages calculated for the whole pilchard

367 population were weighted averages of those for adults with a weigh of 0.76 , and those for

368 juveniles with a weigh of 0.24. The fourth group consisted of the Atlantic mackerel Scomber

369 scombrus, a zooplankton feeder of which the large individuals prefer macrozooplankton (>

$3702000 \mu \mathrm{m})$. The last group was composed of the horse mackerel Trachurus trachurus, a

371 bentho-pelagic species which feeds on both domains (Table 2) (Cabral and Murta, 2002).

\subsubsection{Invertebrates}

374 2.4.3.1 Cephalopods

375 From bottom-trawl surveys conducted annually in autumn in the Bay of Biscay (EVHOE 376 IFREMER cruises), the more abundant pelagic cephalopods in the area appeared to be the 377 broadtail short-finned squid Illex coindetii, the European flying squid Todarodes sagittatus, 378 and four squid species belonging to the Loliginidae family, Loligo spp. and Alloteuthis spp. 379 The most abundant benthic cephalopods were the horned octopus Eledone cirrhosa and the 380 common octopus Octopus vulgaris, together with species of the Sepiidae family. As there has 381 been little systematic study of catchability and gear selectivity in cephalopods, their biomass 382 was left to be estimated by Ecopath, using an $E E$ of 0.95 . This value was justified by their 383 commercial exploitation in the ecosystem. For these groups, wet body weights were converted 
384

to dry weights then to carbon contents using conversion factors of 0.192 and 0.402 respectively (Brey et al., 2010) (Table 1).

The $P / B$ and $Q / B$ ratios corresponded to the values proposed by Sanchez and Olaso (2004) for the Cantabrian Sea. The $P / Q$ ratio was unusually high for animals of this size, in relation to the special eco-physiological characteristics of cephalopods which allow rapid growth (Jackson and O'Dor, 2001).

In the same way, diet composition was roughly estimated from information gathered for the southern part of the Bay. Part of their diet includes pelagic shrimps, which are considered as macrozooplankton in the present study (Table 2).

\subsubsection{Suprabenthic and benthic invertebrates}

Suprabenthic/benthic invertebrates were sampled in 2001 in late spring in the "Grande Vasière" (INTRIGAS II survey). Species were grouped into six compartments according to size, feeding ecology and position regarding the seafloor: "suprabenthic invertebrates" (crustacean suspension feeders mainly members of the Euphausiids family), "metazoan meiofauna" (largely dominated by nematodes), "surface suspension and deposit feeders invertebrates" (various species pertaining to polychaetes, bivalves and crustacean decapods), "sub-surface deposit feeders invertebrates" (eight species of polychaetes, sea urchins and sea cucumbers), "necrophagous benthic invertebrates" (four species of isopods), "carnivorous benthic invertebrates" (polychaetes and crustacean decapods such as the Norwegian lobster Nephrops norvegicus). The biomass was obtained from Duchemin et al. (2008), Le Loc'h (2004), Le Loc'h et al. (2008) as ash-free dry weight and converted to carbon content using a factor of 0.4 (Steele, 1974) (Table 1).

The $P / B$ ratio was estimated from Schwinghamer et al. (1986):

$P / B=0.525 \times W^{\wedge}(-0.304)$ 
with $W$, mean body mass converted to an energy equivalent using conversion factor $(1 \mathrm{~g} \mathrm{C}=$

$410 \quad 11.4$ kcal; Platt and Irwin (1973)).

411 The $P / Q$ ratio, also called the gross food conversion efficiency $(G E)$, was preferentially

412 entered in the model. Indeed, relevant values are available from the literature and typically

413 range from 0.05 to 0.3 (Christensen and Pauly, 1993).

414 Dietary profiles were determined from stable isotope analysis (Le Loc'h et al., 2008) (Table

$4152)$.

416

\subsubsection{Zooplankton}

418 Microzooplankton includes protozoans $<200 \mu \mathrm{m}$, mostly ciliates and heterotrophic

419 flagellates. It was studied in 2004 through four seasonal surveys at three stations located in

420 front of the Gironde River (MICRODYN survey) and three spring surveys in the southern

421 Bay of Biscay in 2003, 2004 and 2005 (PELGAS IFREMER cruises). The cell volume was

422 converted into carbon units using allometric relationships and/or factors (for a complete

423 review of sampling and sample treatments, see Marquis et al. (in press)). Annual $Q / B$ ratio

424 was the intermediate value between the estimate of Sanchez and Olaso (2004) for the

425 Cantabrian Sea and the calculation from phytoplankton grazing experiments on Gironde

426 plume waters (Landry and Hassett, 1982). An ecotrophic efficiency of 0.95 was assumed for

427 this compartment.

428 Mesozooplankton $([200-2000] \mu \mathrm{m})$ consists mostly of metazoans with copepods

429 predominating and macrozooplankton $(>2000 \mu \mathrm{m})$ consists mainly of metazoans with

430 decapods and jelly plankton (tunicates, cnidarians) predominating. The samples were obtained

431 during BIOMAN surveys covering the South-East of the Bay of Biscay in spring (May and

432 June) for the period 1999-2002 (Irigoien et al., 2009). Achievement of reliable estimates of

433 biomass was based on the statistical relationship between zooplankton sample volume, easily 
434 estimated by digital image analysis, and the corresponding organic $\mathrm{C}$ and $\mathrm{N}$ contents of paired 435 aliquots samples. The semi-automatic method used here allowed estimating individual bio436 volume but not the taxonomic composition of zooplankton. So, gelatinous zooplankton which 437 has vastly different biological parameters could not be isolated as a specific Ecopath 438 compartments in the present model. The full procedure was described in Alcaraz et al. (2003). 439 Annual $Q / B$ ratios were taken from Sanchez and Olaso (2004) for the Cantabrian Sea. An 440 ecotrophic efficiency of 0.95 was assumed (Table 1 and 2).

\subsubsection{Primary producers, bacteria and detritus}

443 These compartments were characterized during 14 IFREMER surveys performed over nine 444 years from 1994 to 2002, in various seasons, covering the spread of the Gironde and Loire 445 plumes as well as a larger proportion of the Bay of Biscay continental shelf (see Labry et al. 446 (2002) for a description of full sampling and sample treatments). Most of the data were comprised between 1998 and 2002 and as a consequence, matched with the period covered by data gathered for other compartments (see the second supplementary material).

449 Total chlorophyll $a$ was determined after size-fractioning filtration between nano- and 450 microplankton (size $>3 \mu \mathrm{m}$ ) and picoplankton (size $<3 \mu \mathrm{m}$ ) and analysed by fluometric acidification procedure (Yentsch and Menzel, 1963). A ratio of carbon to chlorophyll $a$ of

$45250: 1$ was taken for conversion. Phytoplankton production was determined by the in situ ${ }^{14} \mathrm{C}$ 453 method (Steeman-Nielsen, 1952).

454 A significant import of allochthonous material probably derives from large rivers flowing into 455 the Bay of Biscay. A value of $454 \mathrm{~kg} \mathrm{C} \cdot \mathrm{km}^{-2} \cdot \mathrm{year}^{-1}$ was evaluated from Abril et al. (2002) and 456 the mean discharge value of these systems (www.hydro.eaufrance.fr).

457 Bacteria were fixed, stained and counted by epifluorescence microscopy (Porter and Feig, 458 1980). Bacterial production was estimated using the method based on the tritiated thymidine 
incorporation into DNA (Furhman and Azam, 1982). Values were converted into biomass and

460 bacterial production assuming a cell content of 16 femtogram of carbon. The biomass was

461 multiplied by two to take into account both pelagic and benthic bacteria populations. It is not

462 possible to estimate the $Q / B$ ratio for groups that feed exclusively on detritus. $P / Q$ ratio for

463 bacteria was derived from the paper by Vézina and Platt (1988) (Table 1 and 2). In Ecopath,

464 detritus is not assumed to respire, although it would if bacteria were considered part of the

465 detritus. This is why it was better to create a separate group for the detritus-feeding bacteria.

466

\subsubsection{Placing the fishery into the system: landings and discards}

Total French catches from the Bay of Biscay exceeded 90000 tons in 1997. Anchovy

(Engraulis encrasicolus) and pilchard (Sardina pilchardus) represented over half the pelagic

catch, while hake (Merluccius merluccius), sole (Solea solea) and anglerfish (Lophius

piscatorius and L. budegassa) dominated the demersal catch. The major French shellfish accounted for less of 2500 tons annually from the Bay of Biscay. Catches of cuttlefish (Sepia officinalis) and squid (Loligo vulgaris and L. forbesii) vary from year to year depending on their relative abundance; landings exceeded 6000 tons in 1997 (OSPAR Commission, 2000).

479 division VIIIa and $\mathrm{b}$ averaged over the 1998-2002 period for surveyed stocks (ICES, 2004)

480 and on French landings statistics for the year 2002 for the main other targeted species.

481 Among suprabenthic and benthic invertebrates, the Norwegian lobster has the greatest

482 economic importance. Catches for this species were also available in the above-mentioned 483 reference. 
Cephalopod landings were taken from the relevant ICES working group (WGCEPH; ICES (2005a)) and were averaged over the 1996-2003 period. Since available landings included captures from division VIIIc as well, $86 \%$ of the total value was considered to take into account the relative VIIIab/VIIIabc surfaces.

In pelagic fisheries, discarding occurs in a sporadic way compared to demersal fisheries.

Discard estimates are still not available for sardine and anchovy; however, given their high economic value, discard levels are thought to be low. Discard data for cephalopods are still not homogeneously collected by EU member countries. For these compartments, discards were set to zero in the model. Discards for benthic and demersal species were obtained from direct observations on Nephrops trawlers operating in the Bay of Biscay, 69 hauls being sampled over the whole 1998 year (Table 1).

\subsection{Trophic structure and ecological network analysis}

A flow diagram was created to synthesise the main trophic interactions in the ecosystem. Furthermore, to provide a quantitative description of the ecosystem structure, the effective trophic level $(T L)$ and the omnivory index $(O I)$ were calculated for each functional group, along with the transfer efficiencies $(T E)$ between successive aggregated trophic levels along a modified Lindeman spine (Table 1). OI is a measure of the variance in trophic level of the prey of a given group. Ecosystem state and functioning were characterized by the total system throughput or activity (TST), which quantifies how much matter the system processes, Finn's cycling index $(F C I)$, which measures the relative importance of cycling to this total flow, and the total primary production to total respiration ratio $(P p / R)$, which expresses the balance between energy that is fixed and energy that is used for maintenance. The average residence time for energy in the system was estimated as the ratio of total system biomass to the sum of all respiratory flows and all exports (Herendeen, 1989). It has been assumed that the residence 
time of particles in a system increases to a maximum during succession, as a result of

510 increasing ecological organisation. The connectance index $(C I)$ and the system omnivory

511 index (SOI) were regarded as two indices reflecting the complexity of the inner linkages

512 within the ecosystem. Taking into account both the size of the ecosystem in terms of flows

513 (TST) and organization (information content), ascendency $(A)$ has been proposed as an index

514 to characterize the degree of development and maturity of an ecosystem (Ulanowicz, 1986).

515 Capacity $(C)$ represents the upper limit of $A$. The relative ascendency measure $(A / C)$ is the 516 fraction of the potential level of organization that is actually realized (Ulanowicz, 1986). It is

517 hypothesized that high values of this index are related to low levels of stress in the system and 518 vice-versa. Hence disturbance activities, like fishing, are expected to produce a decrease in $A$ 519 (Wulff and Ulanowicz, 1989). The complement to $A$ is System Overhead $(O)$, which 520 represents the cost to an ecosystem for circulating matter and energy (Monaco and 521 Ulanowicz, 1997). Thus, $O$ effectively represents the degrees of freedom a system has at its 522 disposal to react to perturbations (Ulanowicz, 1986).Values were compared with those 523 provided by Sanchez and Olaso (2004) and Jimeno (2010) and for other comparable shelf 524 ecosystems (summary table in Trites et al. (1999)). Finally, the mixed trophic impact (MTI) 525 routine indicates the effect that a small increase in the biomass of one (impacting) group will 526 have on the biomass of other (impacted) groups (Ulanowicz and Puccia, 1990). Particular 527 attention was paid to the impacts of fisheries activities on higher trophic-level ecosystem 528 components. Fishing activities were further described using the mean trophic level of the 529 catches $\left(T L_{c}\right)$ and the primary production required to sustain harvest $(P P R) . T L_{c}$ reflects the 530 strategy of a fishery in terms of food-web components selected, and is calculated as the 531 weighted average of $T L$ of harvested species. The $P P R$ required to sustain fisheries has been 532 considered as an ecological footprint that highlights the role of fishing, in channelling marine 533 trophic flows toward human use. To assess the effects of export from the system due to 
534 fishing activities, the $L$ index has been applied (Libralato et al., 2008). It is based on the

535 assumption that the export of secondary production due to fisheries reduces the energy

536 available for upper ecosystem levels, thus resulting in a loss of secondary production. The

537 index that allows quantifying the effects of fishing at an ecosystem level is calculated as:

$538 L=-P P R \times T E^{T L_{c}-1} / P p \times \ln (T E)$

539 with $P p$ the primary production of the system. Estimates of $P P R$ and $P p$ were based on the 540 primary producers' food chain and also by including detrital production. It is possible to 541 associate with each index value a probability of the ecosystem being sustainably fished $\left(P_{\text {sust }}\right.$,

542 Libralato et al. (2008), Coll et al. (2008)). At the same time, the exploitation rates $(F / Z$,

543 fishing mortality to total mortality) by ecological group were also taken into account.

544 Libralato et al. (2006) presented an approach for estimating without bias the

545 "keystoneness" $(K S)$ of living functional groups by combining their overall impact on the 546 system (estimated from the MTI matrix) and their biomass proportion. Keystones are defined 547 as relatively low biomass species with high overall effect. From the positive and negative 548 contribution to the overall effect, it is possible to calculate the bottom-up and top-down

549 effects that contribute to the keystoneness index. The relative importance of top-down or 550 bottom-up trophic controls in continental shelf ecosystems has important implications for how 551 ecosystems respond to perturbations (e.g. Frank et al. (2007)).

\section{3. Results}

554 The initial model was not balanced, since they were some ecotrophic efficiencies greater than

555 1. Contrarily, gross food conversion efficiencies were mostly acceptable. Biomass and 556 production estimates of most demersal fish, sardine and anchovy were insufficient to support 557 consumption by mackerel and horse mackerel that constitute the two most abundant fish 558 biomass in the area. More importantly, the biomass of horse mackerel was left to be estimated 
by the model because of its migratory and bento-pelagic feeding behaviour that renders

560 difficult the estimation of its abundance by scientific surveys. Consequently, proportions of 561 those groups in the diet composition of mackerel and horse mackerel were re-assessed, and

562 when consistent with existing literature, fixed to slightly lower values. In parallel, production 563 terms for piscivorous, piscivorous and benthivorous and benthivorous demersal fish were re564 examined to determine higher acceptable values.

565 Among the five ecological and physiological "rules" that should be met, the one concerning 566 the decrease of biomass and vital rates with trophic levels was the more critical in our model.

567 The biomass spectrum has too much biomass in the middle trophic levels, indicating that the 568 model is most likely too focused on fish taxa (Fig. 2a). Twenty-five percent of compartments 569 were fish species or groups. $Q / B$ and $R / B$ across trophic levels did not show the expected 570 decline contrary to the $P / B$ vital rate (Fig. $2 \mathrm{~b}, \mathrm{c}$ and d). This failure was mostly driven by the 5717 homeotherms' groups at upper trophic levels which tend to have higher values than the 572 trend line because of a higher consumptive demands per unit body mass than poikilotherms. 573 The normal decomposition pattern was more marked when plotting total or scaled values of $P$, $574 Q$ and $R$. The unique vital rate ratio approaching 1 concerned zooplankton which had a 575 biomass in the same order of that of phytoplankton. This is the sole reasonable exception to 576 this diagnostic given the high productivity and low standing stock biomass of primary 577 producers.

578 The flow diagram clarified the connections between levels (Fig. 3). Benthic and pelagic food 579 chains appeared to be linked mainly in their upper ranges by demersal fishes, particularly 580 suprabenthivorous species. They optimize foraging benefits by feeding from both systems and 581 they are, in turn, consumed by a large panel of pelagic top-predators. $O I$ in this study ranged 582 between 0.037 and 1.914 and it was lowest for the common dolphin, which feeds almost 583 exclusively on high-value pelagic species, and for the large hake, which preys solely on other 
584 fish with $T L$ values in the same range (Table 1 and 2). In contrast, other marine top-predators

585 appeared far less specialized, with a significant proportion of their diet coming from imports

586 to the system, assigned by Ecopath to a mid-trophic level position (TL II+), or from dead

587 discarded organisms, assigned to a basal trophic level (TL I).

588 The ecosystem consisted of five main aggregated trophic levels; biomass values for trophic

589 levels VI to XII were extremely small. Transfer efficiencies between successive discrete

590 trophic levels were regular from lower to higher trophic levels, the mean along this spine

591 being $16.8 \%$. The primary producers, detritus and discarded organisms in $T L$ I took $47.5 \%$ of

592 the throughput of the entire system. TL II was mainly bacteria, zooplankton and

593 benthic/suprabenthic invertebrates representing $42.9 \%$ of the total throughput. Thus, most of

594 the activity (90\%) in terms of flow occurred in the lower part of the food web (Fig. 4).

595 The system was estimated to process $93910^{3} \mathrm{~kg} \mathrm{C} \cdot \mathrm{km}^{-2} \cdot \mathrm{year}^{-1}$ (TST), with $34.5 \%$ of the total 596 throughput being recycled $(F C I)$. The overall residence time was calculated to be 0.046 years

597 equivalent to 17 days. The herbivory to detritivory ratio that quantifies the flow along grazing 598 and detrital food webs is an indication of the importance of detrital components in the system 599 and was equal to 0.76 (Fig. 4). In addition, the $E E$ of detritus was estimated to be 0.972 ,

600 indicating that more or less all the energy entering this compartment is re-used in the system.

601 All these elements suggested a strongly detritus-based trophic organization, with an intensive 602 use of particulate organic matter as a food source. The primary production to respiration ratio $603(P p / R)$ was 1.037. Concerning the two proxies for food-chain complexity (Table 3$)$, the global 604 omnivory of 0.212 (SOI) is a relatively "intermediate" value when compared with those 605 obtained for other shelf ecosystems in the world and with outputs from previous Bay of 606 Biscay models. The connectance of the trophic compartments of $0.213(C I)$ was consistent 607 with previous estimates but falls in the lower range. The system showed a relatively low value 608 of $A / C(22.7 \%)$ and conversely a high value of $O / C, A, O$ and $C$ being respectively874,288, 
610 French Atlantic shelf, i.e. $31 \%$ and $69 \%$.

611 The mixed trophic impact routine underlined the fact that marine top-predators had very

612 limited direct or indirect impacts on other trophic groups of the model. Among them, the

613 bottlenose dolphin caused the most pronounced effect (Fig. 5). Fisheries had a direct negative

614 impact on demersal fish stocks, particularly marked for piscivorous species such as large

615 hakes. Fishery wastes, on the other hand, appeared beneficial to surface feeders. Fishing

616 activities could in turn, be positively affected by a small increase in the targeted species, but

617 also by a limited amount of their main food sources, which in the case of forage fish are

618 composed of mesozooplanktonic organisms. In addition, fisheries were characterized by a $T L_{c}$

619 of 3.75 , a $P P R$ of $14.82 \%$ and a $L$ index of 0.06 calculated using a $P p$ equal to $445,931 \mathrm{~kg}$

$620 \mathrm{C} \cdot \mathrm{km}^{-2} \cdot \mathrm{year}^{-1}$ and an average transfer efficiency $T E$ across trophic levels of $16.8 \%$. This $L$

621 value resulted in a probability of having been subjected to a sustainable fishing regime of

$62229.86 \%$. Exploitation rates by ecological group ranged between 0.013 for the carnivorous

623 benthic invertebrates and 0.372 for the piscivorous demersal fish, with a median of 0.117 .

624 Another important feature of the MTI matrix concerned the joint favourable effect of sardine,

625 pilchard and sprat on apex predators. The influence of detritus as a structuring compartment

626 highlighted in the previous paragraph was reinforced by its positive effect on various groups,

627 with the exception of primary producers, for which indirect negative influences predominated.

628 Among consumers and producers, the keystone functional groups belonged to the plankton

629 compartments: large phytoplankton, micro- and mesozooplankton (Fig. 6). The bottom-up

630 effect, evaluated through the proportion of positive values contributing to the overall effect

631 was 83,43 and $70 \%$ respectively.

632 A sensitivity analysis revealed that the main results concerning the functioning of the

633 ecosystem were not affected by lower $E E$ for zooplankton. $E E$ were set to lower values for the 
634 three zooplankton compartments, i.e. $0.45,0.35$ and 0.35 for macro-, meso- and

635 microzooplankton respectively, and the model was rerun. The herbivory to detritivory ratio

636 calculated using the Lindeman spine was equal to 0.76 with current setting and to 0.56 with

637 lower values of $E E$. Adding to this, the keystone species identified were the three same

638 compartments (mesozooplankton, large phytoplanktonic cells and microzooplankton), with

639 both sets of $E E$.

640

\section{4. Discussion}

642 Even though our Ecopath model was validated to meet certain standardization requirements 643 on the basis of the PREBAL, gaps exist particularly on model structure that was most likely 644 too focused on fish and that included numerous homeotherms' groups. This particularity of 645 our model was linked to future research questions that would be addressed with the present 646 model on the Bay of Biscay. They necessitate mono-specific boxes for each small pelagics 647 and marine mammals' species frequenting the area. Model structure was recognized in many 648 occasions to greatly influence the effectiveness for a model to capture real ecosystem 649 properties (Fulton et al., 2003).

650

651 4.1 Late successional position and implications for stability

652 According to Odum (1969), the "strategy" of long-term evolutionary development of the 653 biosphere is to increase homeostasis with the physical environment, in the sense of achieving 654 maximum protection from its perturbations through a large, diverse and complex organic 655 structure. The author proposed 24 attributes to characterize ecosystem development from 656 "young" to "late" successional stages (the full list of attributes is given in the third 657 supplementary material; Christensen (1995)). A careful analysis of the present system's 658 characteristics revealed that detritus is central to energy flow within the Bay of Biscay 
continental shelf food web. This finding was confirmed by the Cantabrian Sea model (Sanchez and Olaso, 2004) that covered a small portion of the Bay presenting distinct hydromorphological characteristics and the model of Jimeno (2010) that encompassed the same area as our model but that was built with fewer specific local data. In these two previous attempts, detritus accounted for $19.3 \%$ and $39 \%$ of total consumption and constituted one of the main energy flow inputs as well. In the above-mentioned theory of ecosystem development, this (among other elements) is strongly characteristic of the community energetics of mature stages of ecosystem development. These detritus-based systems were demonstrated to be more likely to support energetically feasible food chains and to be more resilient than ecosystems based solely on primary production. The stabilizing effect of detritus on these systems is the result of constant allochthonous imports and/or a longer residence time of energy linked to internal cycling (Moore et al., 2004). Odum (1969) identified an increased degree of cycling as an indicator of more mature communities which tend to internalize flows. The high FCI value confirms the strategic position of detritus as a perennial reservoir of energy in the Bay of Biscay. The overall residence time matched with the range already reported for other continental shelves and seas at tropical latitudes (Christensen and Pauly, 1993) and was thus considered as relatively "long” by the present authors. This high value was associated with ecosystem maturity, notably by selecting species with lower growth potential but stronger competitive performances as succession occurs (Odum, 1969). In addition to the dominance of detritivory in the food-web functioning, the $P p / R$ ratio indicates most likely that the system is in a state of organic carbon balance. According to Odum's principles of ecological succession, this feature related to ecosystem bioenergetics is also an excellent index of the relative maturity of the system. $C I$ and $S O I$ are also correlated with system maturity since the internal ecological organization is expected to increase as the system matures. The relatively moderate values for these outputs suggested a "web-like" food 
684 chain with an intermediate level of internal flow complexity, through which energy is

685 transferred efficiently (mean $T E$ far above the widely accepted value of $10 \%$ ). Comparisons

686 with similar or comparable ecosystems (Trites et al., 1999; Jimeno, 2010) suggested that the

687 Bay of Biscay continental shelf is relatively immature (ascendency) and has a high resistance

688 to external perturbations (system overhead). This finding qualified the conclusion derived

689 from other holistic metrics regarding the late maturity stage of the system which seems most

690 probably "still developing".

691 However, the apparent dominance of heterotrophic processes in this food web, mostly based

692 on regenerated production, should be viewed with caution in the light of some methodological

693 choices made during model building. The restriction of the study area to the band between the

694 30-m and 150-m isobaths, corresponding to a zone of relative homogeneity and highly

695 documented, had necessary implications in terms of herbivory to detritivory ratio. First, a

696 large variety of primary producers generally encountered inshore of the $30-\mathrm{m}$ isobath, in the

697 shallowest reaches of the open coast (e.g. seagrasses, macroalgae, and microphytobenthos)

698 were thus partially ignored. Similarly, nutrients and carbon transport between shelves and the

699 open ocean were not taken into account; in the Eastern Biscay, primary production of the

700 shelf has been inferred to depend on oceanic imports (Huthnance et al., 2009).

701

702 4.2 Bottom-up forcing as a general mechanism of control

703 Cury et al. (2003) presented a general overview of the different types of energy flow in

704 marine ecosystems that can be elucidated by plotting time series of predator and prey

705 abundances. They illustrated the bottom-up control with a simplified four-level food web,

706 through which the negative impact of the physical factor on the phytoplankton cascades to the

707 zooplankton, the prey fish and the predators. For the South Bay of Biscay, analysis of

708 quantitative long-term estimates of trophic-level abundances indicates that the coastal 
phytoplankton-mesozooplankton system was mainly bottom-up regulated (Stenseth et al.,

710 2006).

711 On the basis of ecosystem models, Libralato et al. (2006) demonstrated the generally high

712 importance of bottom-up effects in keystoneness for shallow coastal ecosystems and semi-

713 enclosed marine environments such as the Chesapeake Bay, Georgia Strait, Prince Williams

714 Sound in the northern hemisphere. Indeed, the lower part of the trophic web (phyto- and

715 zooplankton) appears very important in these ecosystems, even if benthic groups also tend to

716 have a high keystoneness index $(K S)$. This finding contrasts with the traditional and

717 widespread notion that keystone species/groups tend to be high-trophic-status species exerting

718 a high impact by means of top-down effects (Paine, 1966). Based on the keystoneness

719 analysis, the middle continental shelf of the Bay of Biscay can be added to the list of

720 ecosystems exhibiting this "non-straightforward" pattern of keystoneness. Previous models of

721 the Bay of Biscay ("Biscaya 1970", "Biscaya 1998" (Ainsworth et al., 2001) and "Cantabrian

722 Sea 1994" (Sanchez and Olaso, 2004)) were included in the comparative study of Libralato et

723 al. (2006). It was interesting to note that planktonic compartments appeared as well in groups

724 with the highest keystoneness, strengthening the conclusion that low trophic levels had a

725 major structuring role in this food web.

726 This result, in conjunction with the trophic aggregation in the Lindeman spine, strongly

727 suggests here a "donor driven" ecosystem, and when associated to direct outputs from the

728 MTI matrix, highlighted a marked bottom-up control of small pelagic fish by

729 mesozooplanktonic prey. At upper-trophic-levels, although there is some limited evidence for

730 top-down control of forage fish by predator populations, overall many observations suggest

731 bottom-up control of predator populations by forage fish. Bottom-up control by forage fish is

732 particularly noticeable for seabirds whose feeding strategies are usually less flexible because

733 they are physically constrained to the near-surface layer (Cury et al., 2000). When looking at 
734 the intersection between top-predators and forage fish communities in the present MTI matrix,

735 the same conclusion of a dominant ascending regulation was emphasized.

736 The relative importance of top-down and bottom-up mechanisms may be scale-dependent.

737 Considering the large spatial scale of the study $\left(>100,000 \mathrm{~km}^{2}\right)$, the explanation for this

738 strong bottom-up control may lie in part in the species-energy relationship (Hunt and

739 McKinnell, 2006). Across temperate to polar biomes, at large geographical scales, there is

740 substantial evidence for a broadly positive monotonic relationship between species richness

741 and energy availability. Global scale patterns of animal distribution most probably reflect

742 natural spatial variability in abundance of prey (Gaston, 2000). Within the large-scale $(67,000$

$743 \mathrm{~km}^{2}$ ) fishing areas extending from southern California to western Alaska, a large proportion

$744(87 \%)$ of the spatial variation in long-term, averaged, resident fish production was controlled

745 by bottom-up trophic interactions and this linkage extends to regional areas as small as 10,000

$746 \mathrm{~km}^{2}$ (Ware and Thomson, 2005). The geographical location of the study area was proposed as

747 a potential factor affecting trophic ecosystem regulation. A comparative study including

748 ecosystems of both sides of the Atlantic showed that warmer, southern areas, which are more

749 species rich, exhibited positive predator-prey associations, suggesting that resources limit

750 predator abundance (Frank et al., 2007). The Bay of Biscay was considered as a southern

751 locality in the above-mentioned study.

752

753 4.3 Preliminary implications for ecosystem-based fisheries management

754 First, comparison of two models of the Eastern Bering Sea ecosystem, separated by a forty

755 year interval, revealed that fisheries tend to greatly reduce ecosystem maturity (Trites et al.,

756 1999). The paper of Christensen (1995) included several ecosystems for which the maturity

757 state could be compared before and after a disturbance, notably fishing, and the findings were

758 in all cases in agreement with disturbances leading to a reduction in maturity (Christensen and 
Walters, 2004). The relatively late successional stage highlighted by the ecosystem's

760 attributes did not indicate that such a phenomenon was already taking effect in the Bay of

761 Biscay. Secondly, trophodynamic indicators are particularly useful in synthesizing

762 information made available by means of ecosystem models, for use in ecosystem approach to

763 fisheries and in identifying and tracking ecosystem effects of fishing (Cury et al., 2005). The

764 fairly high percentage of primary production required for harvests in this ecosystem (14.82\%)

765 justifies growing concerns for sustainability and biodiversity. But when compared with

766 previous $P P R$ estimates of $24.2 \%$ for tropical and $35.3 \%$ for non-tropical shelves (Pauly and

767 Christensen, 1995) and the fisheries of the Cantabrian Sea using $36.6 \%$ of the total primary

768 production (Sanchez and Olaso, 2004), the present value probably suggests a rate of

769 exploitation that is more respectful of the carrying capacity of the ecosystem and more

770 appropriate to the objective of sustainable fisheries than previously thought. Given the

771 ecosystem-based reference framework relying on $\% P P R / T L_{c}$ pairs, the Bay of Biscay

772 continental shelf for the period "1994-2005" was classified as an ecosystem that is still

773 "sustainably fished" with a probability around $70 \%$ (Tudela et al., 2005). However, when

774 using the more complex $L$ index, the probability of the ecosystem to be sustainably fished

775 decreased to a considerable lower value (30\%), depicting a much more pessimistic situation

776 regarding the level of system exploitation. This index was different from previous one as it

777 integrates both ecosystem properties and features of fishing activities. This inclusion accounts

778 for differences in ecosystem functioning, thus allowing for meaningful results to be derived

779 for different ecosystem types (Pranovi and Link, 2009). Adding to this, when considering

780 stock specific exploitation rates, values for small pelagics and hake, when compared to those

781 obtained for the same species in the Cantabrian Sea (Sanchez and Olaso, 2004) and to those of

782 closely related species in southern coastal upwelling ecosystems (Coll et al., 2006), pointed

783 towards a moderate exploitation of the resources over the Atlantic French continental shelf. 
784 None of them exceeded 0.5 , the limit reference point at which stocks should be considered as

785 overexploited (Rochet and Trenkel, 2003).

786

787 Conclusions

788 In the context of other models developed for this area, this was the first attempt to

789 characterize the Bay of Biscay continental shelf functioning with an Ecopath model. The three

790 fundamental characteristics of this system that emerged from the present Ecological Network

791 Analysis were that it was most likely detritus-based, relatively mature and bottom-up

792 controlled, with phytoplanktonic and zooplanktonic keystone species. These conclusions had

793 reinforced partial observations made from previous models of the area about the importance

794 of low trophic levels as drivers of the trophic ecosystem functioning. The model developed

795 here and the findings of the present study provide strong methodological support and relevant

796 scientific basis respectively for addressing additional research questions through Ecosim

797 simulations. Dynamic simulations would help in clarifying the exploitation status of the whole

798 ecosystem and in identifying fishing scenarios that allow the maintenance of forage fish

799 stocks, the conservation of top-predators and the persistence of a stable ecosystem. As a

800 second step, Ecosim would be particularly useful in defining food-web indicator(s) in the light

801 of the Marine Strategy Framework Directive. Based on the ecological properties derived from

802 the model developed here, mesozooplankton abundance, diversity and/or biomass could,

803 along with other factors and especially benthic compartments, be reliable indicators of Bay of

804 Biscay continental shelf changes.

805

806 Acknowledgements

807 This research has been supported by the French program PNEC,"Chantier Golfe de

808 Gascogne”, by EU FP7 grant FACTS (Forage Fish Interactions), grant agreement no. 244966 
809 and by the European project REPRODUCE (EratNet-Marifish, WP7). We would like to thank

810 Alain Herbland, the "Bay of Biscay" worksite coordinator during the first phase of the PNEC

811 programme. The authors are also grateful to all those who participated in the field campaigns

812 in the Bay of Biscay and who were involved in data treatment and further developments.

813 Many thanks go to Gérald Duchemin (University of Angers) and to Jean-Claude Sorbe

814 (CNRS, University of Bordeaux 1) for their help on the meiofauna and suprabenthos

815 determination, to Delphine Bonnet (University of Montpellier) for her help on zooplankton

816 data availability, to Xabier Irigoien (AZTI-Tecnalia) for the access to the BIOMAN data and

817 to Begoña Santos and Graham Pierce (Spanish Institute of Oceanography and University of

818 Aberdeen) for their interest in the project and helpful remarks on the marine mammal

819 compartments. Finally, we wish to thank Graham Pierce for assistance with editing the

820 manuscript and the three anonymous referees who provided valuable criticism and helpful

821 comments at the late stage of the paper. 
824 Figure 1: Study area of the Bay of Biscay continental shelf and locations of the main rivers

825 flowing into it. For clarification, ICES divisions VIIIa, b, c and d are also added. Boundaries

826 of the first two are shown with a bold line.

827

828 Figure 2: PREBAL diagnostics depicting values obtained following the manual mass-balance 829 procedure of the model. $T L$ increase from right to left. To offer a better visualization, all 830 primary producers' groups (29 and 30 in Table 1) and zooplankton groups $(25,26$ and 27 in

831 Table 1) are summed. Abbreviations of vital rates are given in section 2.2. "Trophic 832 modelling approach”. Groups depicted in black are primary producers and detritus in figure $8332 \mathrm{a}$ and marine mammals and seabirds in figure $2 \mathrm{~b}, \mathrm{c}$ and $\mathrm{d}$.

834

835 Figure 3: Trophic model of the Bay of Biscay continental shelf. Boxes are arranged using 836 trophic-level $(T L)$ as $\mathrm{y}$-axis and benthic/pelagic partitioning as $\mathrm{x}$-axis. The size of each box is 837 proportional to the biomass it represents. Numbers refer to a code for compartments provided 838 in Table 1.

840 Figure 4: Biomasses, flows, transfer efficiencies are aggregated into integer trophic levels $841(T L)$ in the form of Lindeman spine. $P$ stands for primary producers, $D$ for detritus and $T E$ for 842 trophic efficiencies. In the present work, a modified Lindeman Spine is used to demonstrate 843 the contribution of detritus-based and grazing food chains separately.

845 Figure 5: Combined direct and indirect trophic impacts. Black circles indicate positive 846 impacts and white circles negative impacts. 
848 Figure 6: Keystoneness $(K S)$ for the functional groups of the Bay of Biscay continental shelf 849 food web. For each functional group, the keystoneness index (y-axis) is reported against 850 overall effect (x-axis). Overall effects are relative to the maximum effect measured, thus for $851 \mathrm{x}$-axis the scale is between zero and one. The keystone functional groups are those where the 852 value of the proposed index is close to or greater than zero. Numbers refer to a code for 853 compartments provided in Table 1.

854 
Table 1: Input (regular) and output (bold) parameters for the ecosystem components used in the Bay of Biscay continental shelf model. $T L$ : trophic level, OI: omnivory index, $B$ : biomass $\left(\mathrm{kg} \mathrm{C} \cdot \mathrm{km}^{-2}\right), P / B$ : production/biomass ratio $\left(\right.$ year $\left.^{-1}\right), Q / B$ : consumption/biomass ratio (year $\left.{ }^{-1}\right), E E$ : ecotrophic efficiency, $P / Q$ : gross food conversion efficiency, $U / Q$ : unassimilated consumption, landings $(Y)$ and discards expressed in $\mathrm{kg} C \cdot \mathrm{km}^{-2} \cdot \mathrm{year}^{-1}$, Gear types used to catch each compartment: BT bottom trawler, GN gillnet, LL long-liner, PS purse seiner and PT pelagic trawler.

\begin{tabular}{|c|c|c|c|c|c|c|c|c|c|c|c|}
\hline & $T L$ & $O I$ & $B$ & $P / B$ & $Q / B$ & $E E$ & $P / Q$ & $U / Q$ & $Y$ & Gear type & Discards \\
\hline 1. Plunge and pursuit divers seabirds & 4.36 & 0.499 & 0.27 & 0.09 & 57.66 & $\mathbf{0}$ & 0.002 & 0.2 & & & \\
\hline 2. Surface feeders seabirds & 3.72 & 1.328 & 0.07 & 0.09 & 69.96 & $\mathbf{0}$ & 0.001 & 0.2 & & & \\
\hline 3. Striped dolphins Stenella coeruleoalba & 4.73 & 0.844 & 0.59 & 0.08 & 20.80 & $\mathbf{0}$ & 0.004 & 0.2 & & & \\
\hline 4. Bottlenose dolphins Tursiops truncatus & 5.09 & 0.250 & 2.18 & 0.08 & 21.67 & $\mathbf{0}$ & 0.004 & 0.2 & & & \\
\hline 5. Common dolphins Delphinus delphis & 4.61 & 0.057 & 1.44 & 0.08 & 26.11 & $\mathbf{0}$ & 0.003 & 0.2 & & & \\
\hline 6. Long-finned pilot whale Globicephala melas & 4.65 & 1.914 & 0.83 & 0.05 & 10.34 & $\mathbf{0}$ & 0.005 & 0.2 & & & \\
\hline 7. Harbour porpoise Phocoena phocoena & 4.69 & 0.069 & 0.06 & 0.08 & 40.69 & $\mathbf{0}$ & 0.002 & 0.2 & & & \\
\hline 8. Piscivorous demersal fish & 4.67 & 0.037 & 48.45 & 0.55 & 2.03 & 0.996 & 0.271 & 0.2 & 9.90 & $\mathrm{BT} / \mathrm{LL} / \mathrm{GN}$ & \\
\hline 9. Piscivorous and benthivorous demersal fish & 4.05 & 0.568 & 130 & 0.66 & 3.42 & 0.994 & 0.192 & 0.2 & 3.51 & $\mathrm{BT} / \mathrm{GN}$ & 13.82 \\
\hline 10. Suprabenthivorous demersal fish & 3.49 & 0.114 & 311.20 & 0.55 & 5.30 & 0.995 & 0.104 & 0.2 & 0.15 & BT & 26.79 \\
\hline 11. Benthivorous demersal fish & 3.41 & 0.394 & 28.97 & 0.87 & 5.51 & 0.979 & 0.158 & 0.2 & 4.41 & $\mathrm{BT} / \mathrm{GN}$ & 0.20 \\
\hline 12. Mackerel Scomber scombrus & 3.75 & 0.124 & 450 & 0.50 & 4.40 & 0.879 & 0.114 & 0.2 & 24.57 & $\mathrm{BT} / \mathrm{PS}$ & 0.49 \\
\hline 13. Horse mackerel Trachurus trachurus & 3.69 & 0.086 & 614.79 & 0.36 & 4.00 & 0.950 & 0.091 & 0.2 & 20.27 & $\mathrm{BT} / \mathrm{PS}$ & 1.01 \\
\hline 14. Anchovy Engraulis encrasicolus & 3.67 & & 55.75 & 1.82 & 8.68 & 0.996 & 0.210 & 0.2 & 12.28 & $\mathrm{PT} / \mathrm{PS}$ & \\
\hline 15. Sardine Sardina pilchardus & 3.44 & 0.277 & 184.20 & 0.68 & 8.97 & 0.935 & 0.076 & 0.2 & 9.28 & $\mathrm{PT} / \mathrm{PS}$ & \\
\hline 16. Sprat Sprattus sprattus & 3.67 & & 49.78 & 1.34 & 11.59 & 0.993 & 0.116 & 0.2 & & & \\
\hline 17. Benthic cephalopods & 3.71 & 0.321 & 11.84 & 2.75 & 7.00 & 0.950 & 0.393 & 0.2 & 3.80 & BT & \\
\hline 18. Pelagic cephalopods & 4.45 & 0.362 & 22.45 & 3.20 & 7.50 & 0.950 & 0.427 & 0.2 & 2.27 & BT & \\
\hline 19. Carnivorous benthic invertebrates & 3.23 & 0.210 & 141 & 2.24 & 11.20 & 0.993 & 0.200 & 0.2 & 2.91 & BT & 1.09 \\
\hline 20. Necrophagous benthic invertebrates & 2 & & 16.97 & 1.53 & 15.30 & 0.954 & 0.100 & 0.2 & & & \\
\hline 21. Sub-surface deposit feeders invertebrates & 2.34 & 0.224 & 234.80 & 1.60 & 8.00 & 0.966 & 0.200 & 0.3 & & & \\
\hline 22. Surface suspension and deposit feeders inv. & 2 & & 223.90 & 2.80 & 14 & 0.984 & 0.200 & 0.2 & & & \\
\hline 23. Benthic meiofauna & 2 & & 100 & 10 & 50 & 0.970 & 0.200 & 0.4 & & & \\
\hline 24. Suprabenthic invertebrates & 2.14 & 0.189 & 38 & 20 & 100 & 0.975 & 0.200 & 0.2 & & & \\
\hline 25. Macrozooplankton $(\geq 2 \mathrm{~mm})$ & 2.57 & 0.512 & 120 & 10.47 & 38 & 0.950 & 0.276 & 0.4 & & & \\
\hline 26. Mesozooplankton $(0.2-2 \mathrm{~mm})$ & 2.67 & 0.381 & 638 & 16.44 & 80 & 0.950 & 0.206 & 0.4 & & & \\
\hline 27. Microzooplankton $(\leq 0.2 \mathrm{~mm})$ & 2.18 & 0.154 & 894 & 45.05 & 316 & 0.950 & 0.143 & 0.4 & & & \\
\hline 28. Bacteria & 2 & & 394 & 115 & 328.57 & 0.811 & 0.350 & 0.5 & & & \\
\hline 29. Large phytoplankton $(\geq 3 \mu \mathrm{m})$ & 1 & & 1046 & 119 & & 0.851 & & & & & \\
\hline
\end{tabular}


30. Small phytoplankton $(<3 \mu \mathrm{m})$

448

151

0.752

31. Discards

46.67

0.788

32. Pelagic detritus

0.217

0.972

${ }^{a}$ Pelagic detritus biomass was entered preferentially in the model as its estimation was more precise compared to the one of benthic detritus.

Detritus imports to the system were estimated to be $454 \mathrm{~kg} \mathrm{C} \cdot \mathrm{km}^{-2} \cdot \mathrm{year}^{-1}$ 
Table 2: Predator/prey matrix (column/raw). The fraction of one compartment consumed by another is expressed as the fraction of the total diet, the sum of each column being equal to one.

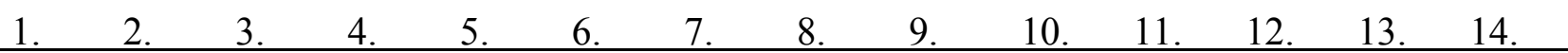

1. Plunge and pursuit divers seabirds

2. Surface feeders seabirds

3. Striped dolphins Stenella coeruleoalba

4. Bottlenose dolphins Tursiops truncatus

5. Common dolphins Delphinus delphis

6. Long-finned pilot whale Globicephala melas

7. Harbour porpoise Phocoena phocoena

8. Piscivorous demersal fish

9. Piscivorous and benthivorous demersal fish

10. Suprabenthivorous demersal fish

$\begin{array}{lllll}0.014 & 0.335 & 0.015 & 0.002 & 0.011\end{array}$

11. Benthivorous demersal fish

12. Mackerel Scomber scombrus

13. Horse mackerel Trachurus trachurus

14. Anchovy Engraulis encrasicolus

15. Sardine Sardina pilchardus

16. Sprat Sprattus sprattus

17. Benthic cephalopods

18. Pelagic cephalopods

19. Carnivorous benthic invertebrates

20. Necrophagous benthic invertebrates

$\begin{array}{llllllll}0.097 & 0.169 & 0.031 & 0.085 & 0.240 & 0.150 & 0.040 & 0.010\end{array}$

21. Sub-surface deposit feeders invertebrates

22. Surface suspension and deposit feeders invertebrates

0.100

$\begin{array}{llllllll}0.345 & 0.081 & 0.004 & 0.006 & 0.216 & 0.180 & 0.055\end{array}$

23. Benthic meiofauna

24. Suprabenthic invertebrates

25. Macrozooplankton ( $\geq 2 \mathrm{~mm})$

26. Mesozooplankton $(0.2-2 \mathrm{~mm})$

27. Microzooplankton $(\leq 0.2 \mathrm{~mm})$
$\begin{array}{lll}0.148 & 0.125 & 0.032\end{array}$
$\begin{array}{lll}0.012 & 0.050 & 0.010\end{array}$
0.010

\begin{tabular}{|c|c|c|c|c|c|c|c|c|c|c|c|c|}
\hline 0.090 & 0.070 & 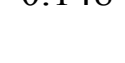 & 0.023 & 0.056 & 0.004 & 0.009 & 0.100 & 0.09 & 0.005 & & 0.033 & 0.005 \\
\hline 0.140 & 0.070 & & 0.132 & 0.050 & 0.039 & 0.276 & 0.220 & 0.135 & 0.005 & 0.020 & 0.030 & 0.005 \\
\hline 0.070 & 0.130 & 0.002 & 0.002 & 0.226 & & 0.003 & 0.130 & 0.022 & 0.005 & & 0.011 & 0.005 \\
\hline 0.380 & 0.210 & & 0.031 & 0.449 & 0.006 & 0.213 & 0.115 & 0.040 & 0.005 & & 0.009 & 0.007 \\
\hline \multirow[t]{11}{*}{0.140} & 0.110 & & 0.009 & 0.080 & & & 0.055 & 0.018 & 0.005 & & 0.007 & 0.005 \\
\hline & & 0.006 & & 0.032 & 0.243 & 0.009 & & 0.010 & 0.002 & 0.003 & & \\
\hline & & 0.122 & 0.093 & 0.025 & 0.006 & 0.008 & & 0.005 & 0.003 & 0.007 & 0.005 & 0.010 \\
\hline & & & & & & & & 0.275 & & 0.200 & & 0.020 \\
\hline & & & & & & & & 0.020 & & 0.050 & & \\
\hline & & & & & & & & 0.030 & & 0.120 & & \\
\hline & & & & & & & & 0.220 & & 0.540 & & \\
\hline & & & & & & & & 0.010 & 0.038 & & & 0.010 \\
\hline & 0.120 & & & & 0.050 & & & & 0.175 & & 0.200 & 0.150 \\
\hline & & & & & & & & & 0.410 & & 0.655 & 0.723 \\
\hline & & & & & & & & & & & 0.033 & 0.050 \\
\hline
\end{tabular}

28. Bacteria

29. Large phytoplankton $(\geq 3 \mu \mathrm{m})$

30. Small phytoplankton $(<3 \mu \mathrm{m})$

31. Discards

$0.080 \quad 0.290$

0.020

0.010

32. Pelagic detritus 
Table 2: (continued)

1. Plunge and pursuit divers seabirds

2. Surface feeders seabirds

3. Striped dolphins Stenella coeruleoalba

4. Bottlenose dolphins Tursiops truncatus

5. Common dolphins Delphinus delphis

6. Long-finned pilot whale Globicephala melas

7. Harbour porpoise Phocoena phocoena

8. Piscivorous demersal fish

9. Piscivorous and benthivorous demersal fish

10. Suprabenthivorous demersal fish

11. Benthivorous demersal fish

12. Mackerel Scomber scombrus

13. Horse mackerel Trachurus trachurus

14. Anchovy Engraulis encrasicolus

15. Sardine Sardina pilchardus

16. Sprat Sprattus sprattus

17. Benthic cephalopods

18. Pelagic cephalopods

19. Carnivorous benthic invertebrates

20. Necrophagous benthic invertebrates

21. Sub-surface deposit feeders invertebrates

22. Surface suspension and deposit feeders invertebrates

23. Benthic meiofauna

24. Suprabenthic invertebrates

25. Macrozooplankton $(\geq 2 \mathrm{~mm})$

26. Mesozooplankton $(0.2-2 \mathrm{~mm})$

27. Microzooplankton $(\leq 0.2 \mathrm{~mm})$

15. 16.

17. 18

8. 19

9. 20.

21. 22

23. 24

24. 25

25. $26 . \quad 27.28$.

28. Bacteria

29. Large phytoplankton $(\geq 3 \mu \mathrm{m})$

30 . Small phytoplankton $(<3 \mu \mathrm{m})$

31. Discards

32. Pelagic detritus

Import

$\begin{array}{lll}0.060 & 0.100 & \\ & 0.070 & 0.005 \\ 0.002 & & \\ & 0.190 & \\ & 0.085 & \\ & 0.080 & \\ & 0.057 & \\ & 0.073 & \\ 0.040 & 0.035 & 0.004 \\ & 0.050 & 0.005 \\ 0.210 & 0.050 & 0.051 \\ & & 0.005 \\ 0.079 & & 0.205 \\ 0.079 & & 0.270 \\ & & 0.210 \\ 0.180 & 0.090 & 0.035 \\ 0.350 & 0.090 & 0.060 \\ & 0.030 & 0.110\end{array}$

0.110
0.340

\author{
$\begin{array}{lll}0.050 & 0.200 & 0.050\end{array}$ \\ $\begin{array}{lllll}0.050 & 0.200 & 0.500 & 0.040\end{array}$ \\ 0.130
}

$\begin{array}{llllll}0.600 & 0.100 & 0.900 & 0.600 & 0.300 & 0.290\end{array}$

0.180

$0.010 \quad 0.020$

$\begin{array}{lllll}0.030 & 0.980 & 0.660 & 0.400 & 0.900\end{array}$ $\begin{array}{lll}0.150 & 0.360 & 1\end{array}$ 
Table 3: Values taken by indices (SOI and $C I$ ) reflecting the complexity of the inner linkages within the ecosystem for the present model and previous attempts to modelize parts of the Bay of Biscay continental shelf.

\begin{tabular}{llll}
\hline & Present model & $\begin{array}{l}\text { French Atlantic shelf } \\
(\text { Jimeno, 2010) }\end{array}$ & $\begin{array}{l}\text { Cantabrian Sea } \\
\text { (Sanchez and Olaso, 2004) }\end{array}$ \\
\hline SOI & 0.212 & 0.164 & 0.268 \\
CI & 0.213 & 0.340 & 0.318 \\
\hline
\end{tabular}




\section{References}

Abril, G., Nogueira, M., Etcheber, H., Cabeçadas, G., Lemaire, E., Brogueira, M.J., 2002. Behaviour of organic carbon in nine contrasting European estuaries. Estuarine, Coastal and Shelf Science 54, 241-262.

Ainsworth, C.H., Ferriss, B., Leblond, E., Guénette, S., 2001. The Bay of Biscay, France: 1998 and 1970 models. Fisheries impacts on North Atlantic ecosystems: models and analyses. The Fisheries Centre, University of British Columbia, Vancouver, Canada, pp. 271-313. Alcaraz, M., Saiz, E., Calbet, A., Trepat, I., Broglio, E., 2003. Estimating zooplankton biomass through image analysis. Marine Biology 143, 305-315.

Allen, K.R., 1971. Relation between production and biomass. Journal of Fisheries Research Board of Canada 28, 1573-1581.

Arcos, J.M., 2001. Foraging ecology of seabirds at sea: significance of commercial fisheries in the NW Mediterranean. PhD Thesis, University of Biology, Animal Biology Department, Barcelona, Spain.

Baeta, F., Costa, M.J., Cabral, H., 2009. Trammel nets' ghost fishing off the Portuguese central coast. Fisheries Research 98, 33-39.

Bode, A., Alvarez-Ossorio, M.T., Carrera, P., Lorenzo, J., 2004. Reconstruction of trophic pathways between plankton and the North Iberian sardine (Sardina pilchardus) using stable isotopes. Scientia Marina 68, 165-178.

Boyd, I.A., 2002. Energetics: consequences for fitness. In: Hoelzel, A.R. (Ed.), Marine mammal biology - an evolutionary approach. Blackwell Science, pp. 247-278.

Bradford-Grieve, J.M., Probert, P.K., Nodder, S.D., Thompson, D., Hall, J., Hanchet, S., Boyd, P., Zeldis, J., Baker, A.N., Best, H.A., Broekhuizen, N., Childerhouse, S., Clark, M., Hadfield, M., Safi, K., Wilkinson, I., 2003. Pilot trophic model for subantarctic water over the 
Southern Plateau, New Zealand: a low biomass, high transfer efficiency system. Journal of Experimental Marine Biology and Ecology 289, 223-262.

Brey, T., Müller-Wiegmann, C., Zittier, Z.M.C., Hagen, W., 2010. Body composition in aquatic organisms - A global data bank of relationships between mass, elemental composition and energy content. Journal of Sea Research 64, 334-340.

Browman, H.I., Cury, P., Hilborn, R., Jennings, S., Lotze, H.K., Mace, P.M., Murawski, S., Pauly, D., Sissenwine, M., Stergiou, K.I., Zeller, D., 2004. Perspectives on ecosystem-based approaches to the management of marine resources. Marine Ecology Progress Series 274, 269-303.

Byron, C., Link, J., Costa-Pierce, B., Bengtson, D., 2011. Modeling ecological carrying capacity of shellfish aquaculture in highly flushed temperate lagoons. Aquaculture 314, 8799.

Cabral, H.N., Murta, A.G., 2002. The diet of blue whiting, hake, horse mackerel and mackerel off Portugal. Journal of Applied Ichthyology 18, 14-23.

Certain, G., Bretagnolle, V., 2008. Monitoring seabirds population in marine ecosystem: the use of strip-transect aerial surveys. Remote Sensing of Environment 112, 3314-3322. Certain, G., Masse, J., Van Canneyt, O., Petitgas, P., Doremus, G., Santos, M., Ridoux, V., 2011. Investigating the coupling between small pelagic fish and marine top predators using data collected from ecosystem-based surveys. Marine Ecology Progress Series 422, 23-39. Certain, G., Ridoux, V., Van Canneyt, O., Bretagnolle, V., 2008. Delphinid spatial distribution and abundance estimates over the shelf of the Bay of Biscay. ICES Journal of Marine Science 65, 656-666.

Christensen, V., 1995. Ecosystem maturity - towards quantification. Ecological Modelling 77, $3-32$. 
Christensen, V., Pauly, D., 1992. ECOPATH II - a software for balancing steady-state ecosystem models and calculating network characteristics. Ecological Modelling 61, 169-185. Christensen, V., Pauly, D., (Eds.), 1993. Trophic models of aquatic ecosystems. International Center for Living Aquatic Resources Management; The International Council for the Exploration of the Sea; The Danish International Development Agency, Manila, Philippines. Christensen, V., Walters, C.J., 2004. Ecopath with Ecosim: methods, capabilities and limitations. Ecological Modelling 172, 109-139.

Christensen, V., Walters, C.J., Ahrens, R., Alder, J., Buszowski, J., Christensen, L.B., Cheung, W.W.L., Dunne, J., Froese, R., Karpouzi, V., Kaschner, K., Kearney, K., Lai, S., Lam, V., Palomares, M.L.D., Peters-Mason, A., Piroddi, C., Sarmiento, J.L., Steenbeek, J., Sumaila, R., Watson, R., Zeller, D., Pauly, D., 2009. Database-driven models of the world's large marine ecosystems. Ecological Modelling 220, 1984-1996.

Christensen, V., Walters, C.J., Pauly, D., Forrest, R., 2008. Ecopath with Ecosim version 6: user guide.

Coll, M., Libralato, S., Tudela, S., Palomera, I., Pranovi, F., 2008. Ecosystem overfishing in the ocean. PLoS ONE 3, e3881.

Coll, M., Santojanni, A., Palomera, I., Tudela, S., Arneri, E., 2007. An ecological model of the Northern and Central Adriatic Sea: analysis of ecosystem structure and fishing impacts. Journal of Marine Systems 67, 119-154.

Coll, M., Shannon, L.J., Moloney, C.L., Palomera, I., Tudela, S., 2006. Comparing trophic flows and fishing impacts of a NW Mediterranean ecosystem with coastal upwelling systems by means of standardized models and indicators. Ecological Modelling 198, 53-70.

Cury, P., Bakun, A., Crawford, R.J.M., Jarre, A., Quinones, R.A., Shannon, L.J., Verheye, H.M., 2000. Small pelagics in upwelling systems: patterns of interaction and structural changes in "wasp-waist" ecosystems. ICES Journal of Marine Science 57, 603-618. 
Cury, P., Shannon, L.J., Shin, Y.J., 2003. The functioning of marine ecosystems: a fisheries perspective. In: Sinclair, M., Valdimarsson, G. (Eds.), Responsible fisheries in the marine ecosystem. CABI Publishing and Food and Agriculture Organization of the United Nations (FAO), Rome, Italy, pp. 103-125.

Cury, P.M., Shannon, L.J., Roux, J.P., Daskalov, G.M., Jarre, A., Moloney, C.L., Pauly, D., 2005. Trophodynamic indicators for an ecosystem approach to fisheries. ICES Journal of Marine Science 62, 430-442.

Daskalov, G.M., Grishin, A.N., Rodionov, S., Mihneva, V., 2007. Trophic cascades triggered by overfishing reveal possible mechanisms of ecosystem regime shifts. Proceedings of the National Academy of Sciences 104, 10518-10523.

Diaz, P., Santos, J., Velasco, F., Serrano, A., Perez, N., 2008. Anglerfish discard estimates and patterns in Spanish Northeast Atlantic trawl fisheries. ICES Journal of Marine Science $65,1350-1361$.

Duchemin, G., Jorissen, F.J., Le Loc'h, F., Andrieux-Loyer, F., Hily, C., Thouzeau, G., 2008. Seasonal variability of living benthic foraminifera from the outer continental shelf of the Bay of Biscay. Journal of Sea Research 59, 297-319.

Frank, K.T., Petrie, B., Shackell, N.L., 2007. The ups and downs of trophic control in continental shelf ecosystems. Trends in Ecology \& Evolution 22, 236-242.

Froese, R., Pauly, D., 2000. Fishbase 2000 - Concepts, design and data sources.

Fulton, E.A., Smith, A.D.M., Johnson, C.R., 2003. Effect of complexity on marine ecosystem models. Marine Ecology Progress Series 253, 1-16.

Furhman, J.A., Azam, F., 1982. Thymidine incorporation as a measure of heterotrophic bacterioplankton production in marine surface water: evaluation and field results. Marine Biology 66, 109-120.

Gaston, K.J., 2000. Global patterns in biodiversity. Nature 405, 220-227. 
Grémillet, D., Pichegru, L., Kuntz, G., Woakes, A.G., Wilkinson, S., Crawford, R.J.M., Ryan, P.G., 2008. A junk-food hypothesis for gannets feeding on fishery waste. Proceedings of the Royal Society B: Biological Sciences 275, 1149-1156.

Hall-Spencer, J., Allain, V., Fossa, J.H., 2002. Trawling damage to Northeast Atlantic ancient coral reefs. Proceedings of the Royal Society B: Biological Sciences 269, 507-511.

Hall, S.J., 1999. The effects of fishing on marine ecosystems and communities. Blackwell Science.

Heithaus, M.R., Frid, A., Wirsing, A.J., Worm, B., 2008. Predicting ecological consequences of marine top predator declines. Trends in Ecology \& Evolution 23, 202-210.

Herendeen, R., 1989. Energy intensity, residence time, exergy, and ascendency in dynamic ecosystems. Ecological Modelling 48, 19-44.

Heymans, J.J., Baird, D., 2000. A carbon flow model and network analysis of the northern Benguela upwelling system, Namibia. Ecological Modelling 126, 9-32.

Hoenig, J.M., 1983. Empirical use of longevity data to estimate mortality rates. Fishery Bulletin 82, 898-903.

Hunt, G.L., Drew, G.S., Jahncke, J., Piatt, J.F., 2005. Prey consumption and energy transfer by marine birds in the Gulf of Alaska. Deep Sea Research Part II: Tropical Studies in Oceanography 52, 781-797.

Hunt, J.G.L., McKinnell, S., 2006. Interplay between top-down, bottom-up, and wasp-waist control in marine ecosystems. Progress In Oceanography 68, 115-124.

Huthnance, J.M., Holt, J.T., Wakelin, S.L., 2009. Deep ocean exchange with west-European shelf seas. Ocean Science 5, 621-634.

ICES, 2004. Report of the ICES advisory committee on fisheries management and advisory committee on ecosystems, 2004. ICES Advice, Vol. 1. 
ICES, 2005a. Report of the working group of cephalopod fisheries and life history (WGCEPH), By correspondence, ICES CM 2005/G:14.

ICES, 2005b. Report of the working group on the assessment of mackerel, horse mackerel, sardine and anchovy (WGMHSA), ICES CM 2005/ACFM:08.

ICES, 2010. Report of the working group on anchovy and sardine (WGANSA), ICES CM 2010/ACOM:16.

Irigoien, X., Fernandes, J.A., Grosjean, P., Denis, K., Albaina, A., Santos, M., 2009. Spring zooplankton distribution in the Bay of Biscay from 1998 to 2006 in relation with anchovy recruitment. Journal of Plankton Research 31, 1-17.

Jackson, G.D., O'Dor, R.K., 2001. Time, space and the ecophysiology of squid growth, life in the fast lane. Vie et Milieu 51, 205-215.

Jimeno, J.L., 2010. A mass balance model of the Bay of Biscay ecosystem. Master Thesis, AZTI-Tecnalia, Marine research division, area of pelagic resources management, DonostiaSan Sebastián, Spain.

Jorgensen, S.E., Nielsen, S.N., Jorgensen, L.A., 1991. Handbook of ecological parameters and ecotoxicology. Elsevier Science Publishers, Amsterdam, Netherlands.

Labry, C., Herbland, A., Delmas, D., 2002. The role of phosphorus on planktonic production of the Gironde plume waters in the Bay of Biscay. Journal of Plankton Research 24, 97-117. Landry, M.R., Hassett, R.P., 1982. Estimating the grazing impact of marine microzooplankton. Marine Biology 67, 283-288.

Le Loc'h, F., 2004. Structure, fonctionnement, évolution des communautés benthiques des fonds meubles exploités du plateau continental Nord-Gascogne. Thèse de Doctorat, Université de Bretagne Occidentale, Océanographie Biologique, Brest, France. 
Le Loc'h, F., Hily, C., Grall, J., 2008. Benthic community and food web structure on the continental shelf of the Bay of Biscay (North Eastern Atlantic) revealed by stable isotopes analysis. Journal of Marine Systems 72, 17-34.

Leaper, R., Lavigne, D., 2007. How much do large whales eat? Journal of Cetacean Research and Management 9, 179-188.

Léauté, J.P., 1998. European Union fishing fleet in the Bay of Biscay, seen from the sky. Oceanologica Acta 21, 371-381.

Libralato, S., Christensen, V., Pauly, D., 2006. A method for identifying keystone species in food web models. Ecological Modelling 195, 153-171.

Libralato, S., Coll, M., Tudela, S., Palomera, I., Pranovi, F., 2008. Novel index for quantification of ecosystem effects of fishing as removal of secondary production. Marine Ecology Progress Series 355, 107-129.

Link, J.S., 2010. Adding rigor to ecological network models by evaluating a set of prebalance diagnostics: a plea for PREBAL. Ecological Modelling 221, 1580-1591.

Lorance, P., Bertrand, J.A., Brind'Amour, A., Rochet, M.J., Trenkel, V.M., 2009. Assessment of impacts from human activities on ecosystem components in the Bay of Biscay in the early 1990s. Aquatic Living Resources 22, 409-431.

Marquis, E., Niquil, N., Dupuy, C., in press. Does the study of microzooplankton community size structure effectively define their dynamics? Investigation in the Bay of Biscay (France). Journal of Plankton Research.

Meynier, L., Pusineri, C., Spitz, J., Santos, M.B., Pierce, G.J., Ridoux, V., 2008. Intraspecific dietary variation in the short-beaked common dolphin (Delphinus delphis) in the Bay of Biscay: importance of fat fish. Marine Ecology Progress Series 354, 277-287.

Monaco, M.E., Ulanowicz, R.E., 1997. Comparative ecosystem trophic structure of three U.S. mid-Atlantic estuaries. Marine Ecology Progress Series 161, 239-254. 
Moore, J.C., Berlow, E.L., Coleman, D.C., de Ruiter, P.C., Dong, Q., Hastings, A., Johnson, N.C., McCann, K.S., Melville, K., Morin, P.J., Nadelhoffer, K., Rosemond, A.D., Post, D.M., Sabo, J.L., Scow, K.M., Vanni, M.J., Wall, D.H., 2004. Detritus, trophic dynamics and biodiversity. Ecology Letters 7, 584-600.

Nelson, B., 1979. Seabirds: their biology and ecology. A \& W Publishers Inc., New-York, USA.

Nilsson, S.G., Nilsson, I.N., 1976. Numbers, food consumption, and fish predation by birds in Lake Möckeln, Southern Sweden. Ornis Scandinavica 7, 61-70.

Odum, E.P., 1969. The strategy of ecosystem development. Science 164, 262-270.

OSPAR Commission, 2000. Quality Status Report 2000: Region IV - Bay of Biscay and Iberian Coast.

Paine, R.T., 1966. Food web complexity and species diversity. The American Naturalist 100, $65-75$.

Palomares, M.L.D., Pauly, D., 1998. Predicting food consumption of fish populations as functions of mortality, food type, morphometrics, temperature and salinity. Marine and Freshwater Research 49, 447-453.

Pauly, D., 1980. On the interrelationships between natural mortality, growth parameters, and mean environmental temperature in 175 fish stocks. Journal du Conseil Permanent International pour l'Exploration de la Mer 39, 175-192.

Pauly, D., Christensen, V., 1995. Primary production required to sustain global fisheries. Nature 374, 255-257.

Plagànyi, E.E., 2007. Models for an ecosystem approach to fisheries. FAO Fisheries Technical Paper, Vol. 477. 
Plagànyi, E.E., Butterworth, D.S., 2004. A critical look at the potential of Ecopath with Ecosim to assist in practical fisheries management. African Journal of Marine Science 26, 261-287.

Planque, B., Lazure, P., Jégou, A.M., 2004. Detecting hydrological landscapes over the Bay of Biscay continental shelf in spring. Climate Research 28, 41-52.

Platt, T., Irwin, B., 1973. Caloric content of phytoplankton. Limnology and Oceanography 2, 306-309.

Polovina, J.J., 1984. Model of coral reef ecosystem I. The Ecopath model and its application to French Frigate Shoals. Coral Reefs 3, 1-11.

Porter, K.G., Feig, Y.S., 1980. The use of DAPI for identifying and counting aquatic microflora. Limnology and Oceanography 25, 943-948.

Power, M.E., Tilman, D., Estes, J.A., Menge, B.A., Bond, W.J., Mills, L.S., Daily, G., Castilla, J.C., Lubchenco, J., Paine, R.T., 1996. Challenges in the quest for keystones. BioScience 46, 609-620.

Pranovi, F., Link, J.S., 2009. Ecosystem exploitation and trophodynamic indicators: a comparison between the Northern Adriatic Sea and Southern New England. Progress In Oceanography 81, 149-164.

Rochet, M.J., Trenkel, V., 2003. Which community indicators can measure the impact of fishing? A review and proposals. Canadian Journal of Fisheries and Aquatic Sciences 60, 8699.

Sanchez, F., Olaso, I., 2004. Effects of fisheries on the Cantabrian Sea shelf ecosystem. Ecological Modelling 172, 151-174.

Schwinghamer, P., Hargrave, B., Peer, D., Hawkins, C.M., 1986. Partitioning of production and respiration among size groups of organisms in an intertidal benthic community. Marine Ecology Progress Series 31, 131-142. 
Shannon, L.J., Coll, M., Neira, S., Cury, P.M., Roux, J.P., 2009. Impacts of fishing and climate change explored using trophic models. In: Checkley, D.M., Alheit, J., Oozeki, Y., Roy, C. (Eds.), Climate change and small pelagic fish. Cambridge University Press, pp. 158190.

Spitz, J., Mourocq, E., Schoen, V., Ridoux, V., 2010. Proximate composition and energy content of forage species from the Bay of Biscay: high or low quality food? ICES Journal of Marine Science 67, 909-915.

Spitz, J., Richard, E., Meynier, L., Pusineri, C., Ridoux, V., 2006a. Dietary plasticity of the oceanic striped dolphin, Stenella coeruleoalba, in the neritic waters of the Bay of Biscay. Journal of Sea Research 55, 309-320.

Spitz, J., Rousseau, Y., Ridoux, V., 2006b. Diet overlap between harbour porpoise and bottlenose dolphin: an argument in favour of interference competition for food? Estuarine, Coastal and Shelf Science 70, 259-270.

Steele, J.H., 1974. The structure of marine ecosystems. Harvard University Press, Cambridge, USA.

Steeman-Nielsen, E., 1952. The use of radioactive ${ }^{14} \mathrm{C}$ for measuring organic production in the sea. Journal du Conseil Permanent International pour l'Exploration de la Mer 18, 117-140. Stenseth, N.C., Llope, M., Anadón, R., Ciannelli, L., Chan, K.S., Hjermann, D.O., Bagøien, E., Ottersen, G., 2006. Seasonal plankton dynamics along a cross-shelf gradient. Proceedings of the Royal Society B: Biological Sciences 273, 2831-2838.

Tallis, H., Levin, P.S., Ruckelshaus, M., Lester, S.E., McLeod, K.L., Fluharty, D.L., Halpern, B.S., 2010. The many faces of ecosystem-based management: making the process work today in real places. Marine Policy 34, 340-348. 
Trenkel, V.M., Skaug, H.J., 2005. Disentangling the effects of capture efficiency and population abundance on catch data using random effects models. ICES Journal of Marine Science 62, 1543-1555.

Trites, A.W., Livingston, P.A., Vasconcellos, M.C., Mackinson, S., Springer, A.M., Pauly, D., 1999. Ecosystem change and the decline of marine mammals in the Eastern Bering Sea: testing the ecosystem shift and commercial whaling hypotheses. Fisheries Centre Research Reports, Vol. 7(1).

Trites, A.W., Pauly, D., 1998. Estimating mean body masses of marine mammals from maximum body lengths. Canadian Journal of Zoology 76, 886-896.

Tudela, S., Coll, M., Palomera, I., 2005. Developing an operational reference framework for fisheries management on the basis of a two-dimensional index of ecosystem impact. ICES Journal of Marine Science 62, 585-591.

Ulanowicz, R.E., 1986. Growth and development: ecosystem phenomenology. SpringerVerlag, New-York, USA.

Ulanowicz, R.E., Puccia, C.J., 1990. Mixed trophic impacts in ecosystems. Coenoses 5, 7-16. Varela, M., 1996. Phytoplankton ecology in the Bay of Biscay. Scientia Marina 60, 45-53. Vézina, A.F., Platt, T., 1988. Food web dynamics in the oceans. 1. Best-estimates of flow networks using inverse methods. Marine Ecology Progress Series 42, 269-287. Ware, D.M., Thomson, R.E., 2005. Bottom-up ecosystem trophic dynamics determine fish production in the northeast Pacific. Science 308.

Whitehead, J.P., 1985. FAO species catalogue - Clupeoid fishes of the world (suborder: clupeoidei) - An annoted and illustrated catalogue of the herrings, sardines, pilchards, sprats, shads, anchovies and wolf-herrings. FAO, Rome, Italy. 
Wulff, F., Ulanowicz, R.E., 1989. A comparative anatomy of the Baltic Sea and Chesapeake ecosystems. In: Wulff, F., Field, J.G., Mann, K.H. (Eds.), Network analysis in marine ecology - methods and applications. Springer-Verlag, Berlin, Germany, pp. 232-256.

Yentsch, C.S., Menzel, D.W., 1963. A method for the determination of phytoplankton chlorophyll and phaeophytin by fluorescence. Deep Sea Research and Oceanographic Abstracts 10, 221-231. 
The species composition of the four demersal fish compartments in the Bay of Biscay continental shelf ecosystem model.

$\underline{\text { Benthivorous demersal fish }}$

Arnoglossus laterna

Arnoglossus imperialis

Arnoglossus thori

Callionymus lyra

Microchirus variegatus

Solea solea

Chelidonichthys cuculus

Liza ramada

Balistes carolinensis

Enchelyopus cimbrius

Mullus surmuletus

Raja clavata

Raja montagui

Sparus auratus

Microstomus kitt

Callionymus maculatus

Buglossidium luteum

Chelidonichthys obscurus

Dicologlossa cuneata

Lesueurigobius friesii

Leucoraja circularis

Pomatoschistus minutus

Syngnathus acus

Umbrina canariensis

$\underline{\text { Suprabenthivorous demersal fish }}$

Capros aper

Micromesistius poutassou

Argentina silus

Boops boops

Cepola macrophthalma

Ammodytes tobianus

Aphia minuta

Merluccius merluccius (juveniles)

$\underline{\text { Piscivorous and benthivorous demersal fish }}$

Scyliorhinus canicula

Conger conger

Gaidropsarus vulgaris

Lepidorhombus boscii

Lepidorhombus whiffiagonis

Lophius budegassa

Lophius piscatorius

Merlangius merlangus

Trisopterus luscus

Trisopterus minutus 
Argentina sphyraena

Dicentrarchus labrax

Galeorhinus galeus

Leucoraja naevus

Myliobatis aquila

Zeus faber

Spondyliosoma cantharus

Squalus acanthias

Torpedo marmorata

Trachinus draco

Molva molva

Molva dypterygia

Chelidonichthys gurnardus

Mustelus asterias

Pollachius pollachius

Melanogrammus aeglefinus

Chelidonichthys lucerna

Mustelus mustelus

Galeus melastomus

Dasyatis pastinaca

Dicentrarchus punctatus

Diplodus vulgaris

Echiichthys vipera

Helicolenus dactylopterus dactylopterus

Hyperoplus lanceolatus

Labrus mixtus

Lithognathus mormyrus

Pagellus acarne

Pagellus bogaraveo

Phycis blennoides

Scophthalmus maximus

$\underline{\text { Piscivorous demersal fish }}$

Merluccius merluccius

Argyrosomus regius

Torpedo nobiliana

Hexanchus griseus 
Table summarizing campaigns and years of the biomass data for each of the 32 compartments. The 14 Ifremer campaigns used to estimate phytoplankton, bacteria and detritus parameters in the Bay of Biscay continental shelf model were also given in full. PNOCAT, BIOMET and PLAGIA were localized in the Gironde plume, GASPROD in the Loire plume and PELGAS over the continental shelf.

\begin{tabular}{|c|c|c|}
\hline & Campaigns & Periods \\
\hline $\begin{array}{l}\text { 1. Plunge and pursuit divers seabirds } \\
\text { 2. Surface feeders seabirds }\end{array}$ & ROMER/ATLANCET & $2001-2004$ \\
\hline $\begin{array}{l}\text { 3. Striped dolphins Stenella coeruleoalba } \\
\text { 4. Bottlenose dolphins Tursiops truncatus } \\
\text { 5. Common dolphins Delphinus delphis } \\
\text { 6. Long-finned pilot whale Globicephala melas } \\
\text { 7. Harbour porpoise Phocoena phocoena }\end{array}$ & $\begin{array}{l}\text { ROMER/ATLANCET } \\
\text { SCAN } \\
\text { PELGAS }\end{array}$ & $2001-2005$ \\
\hline $\begin{array}{l}\text { 8. Piscivorous demersal fish } \\
\text { 9. Piscivorous and benthivorous demersal fish } \\
\text { 10. Suprabenthivorous demersal fish } \\
\text { 11. Benthivorous demersal fish }\end{array}$ & EVHOE & $1998-2003$ \\
\hline $\begin{array}{l}\text { 12. Mackerel Scomber scombrus } \\
\text { 13. Horse mackerel Trachurus trachurus } \\
\text { 14. Anchovy Engraulis encrasicolus } \\
\text { 15. Sardine Sardina pilchardus } \\
\text { 16. Sprat Sprattus Sprattus }\end{array}$ & PELGAS & $2000-2003$ \\
\hline
\end{tabular}

17. Benthic cephalopods

18. Pelagic cephalopods

19. Carnivorous benthic invertebrates

INTRIGAS II

2001

20. Necrophagous benthic invertebrates

21. Sub-surface deposit feeders invertebrates

22. Surface suspension and deposit feeders inv.

23. Benthic meiofauna

24. Suprabenthic invertebrates

25. Macrozooplankton ( $\geq 2 \mathrm{~mm})$

26. Mesozooplankton $(0.2-2 \mathrm{~mm})$

27. Microzooplankton $(\leq 0.2 \mathrm{~mm})$

28. Bacteria

29. Large phytoplankton $(\geq 3 \mu \mathrm{m})$

30. Small phytoplankton $(<3 \mu \mathrm{m})$

32. Pelagic detritus

BIOMAN

1999-2002

\begin{tabular}{lll} 
& PEGASE & June 1998 \\
& PLAGIA 1 & February 1999 \\
PLAGIA 2 & April 1999 \\
PLAGIA 3 & May 1999 \\
PLAGIA 4 & June 1999 \\
& PLAGIA 5 & July 1999 \\
& PLAGIA 6 & October 1999 \\
& GASPROD & April 2002 \\
& PELGAS & May 2000 \\
& PELGAS & May 2001 \\
\hline 31. Discards & Nephrops trawlers & 1998 \\
\hline
\end{tabular}


The 24 attributes proposed by Odum to define the successional status of an ecosystem. Five attributes were retained in the present study as they can be applied to marine ecosystems and be easily evaluated through "Network Analysis" in Ecopath. They were depicted in bold in the table.

Ecosystem attributes

Developmental stages Mature stages

1/ Gross production/community Community energetics respiration $(\mathbf{P} / \mathbf{R}$ ratio)

2/ Gross production/standing crop biomass $(\mathrm{P} / \mathrm{B}$ ratio)

3/ Biomass supported/unit of energy
flow (B/E ratio)

Greater or less than 1

Approaches 1

4/ Net community production High

5/ Food chains

High

Low

Low

High

Low
Linear, predominantly grazing

Web-like, predominantly detritus

\begin{tabular}{|c|c|c|}
\hline & Community structure & \\
\hline 6/ Total organic matter & Small & Large \\
\hline 7/ Inorganic nutrients & Extrabiotic & Intrabiotic \\
\hline $\begin{array}{l}8 \text { / Species diversity-variety } \\
\text { component }\end{array}$ & Low & High \\
\hline $\begin{array}{l}\text { 9/ Species diversity-equitability } \\
\text { component }\end{array}$ & Low & High \\
\hline 10/ Biochemical diversity & Low & High \\
\hline \multirow[t]{2}{*}{$\begin{array}{l}11 / \text { Stratification and spatial } \\
\text { heterogeneity }\end{array}$} & Poorly organized & Well-organized \\
\hline & Life history & \\
\hline 12/ Niche specialization & Broad & Narrow \\
\hline 13/ Size of organism & Small & Large \\
\hline \multirow[t]{2}{*}{ 14/ Life cycles } & Short, simple & Long, complex \\
\hline & Nutrient cycling & \\
\hline 15/ Mineral cycles & Open & Closed \\
\hline $\begin{array}{l}\text { 16/ Nutrient exchange rate } \\
\text { between organisms and environment }\end{array}$ & Rapid & Slow \\
\hline \multirow[t]{2}{*}{$\begin{array}{l}17 / \text { Role of detritus in nutrient } \\
\text { regeneration }\end{array}$} & Unimportant & Important \\
\hline & Selection pressures & \\
\hline 18/ Growth form & for rapid growth & $\begin{array}{l}\text { for feedback } \\
\text { control }\end{array}$ \\
\hline \multirow[t]{2}{*}{ 19/ Production } & Quantity & Quality \\
\hline & Overall homeostasis & \\
\hline 20/ Internal symbiosis & Undeveloped & Developed \\
\hline 21/ Nutrient conservation & Poor & Good \\
\hline 22/ Stability & Poor & Good \\
\hline 23/ Entropy & High & Low \\
\hline 24/ Information & Low & High \\
\hline
\end{tabular}


Click here to download high resolution image

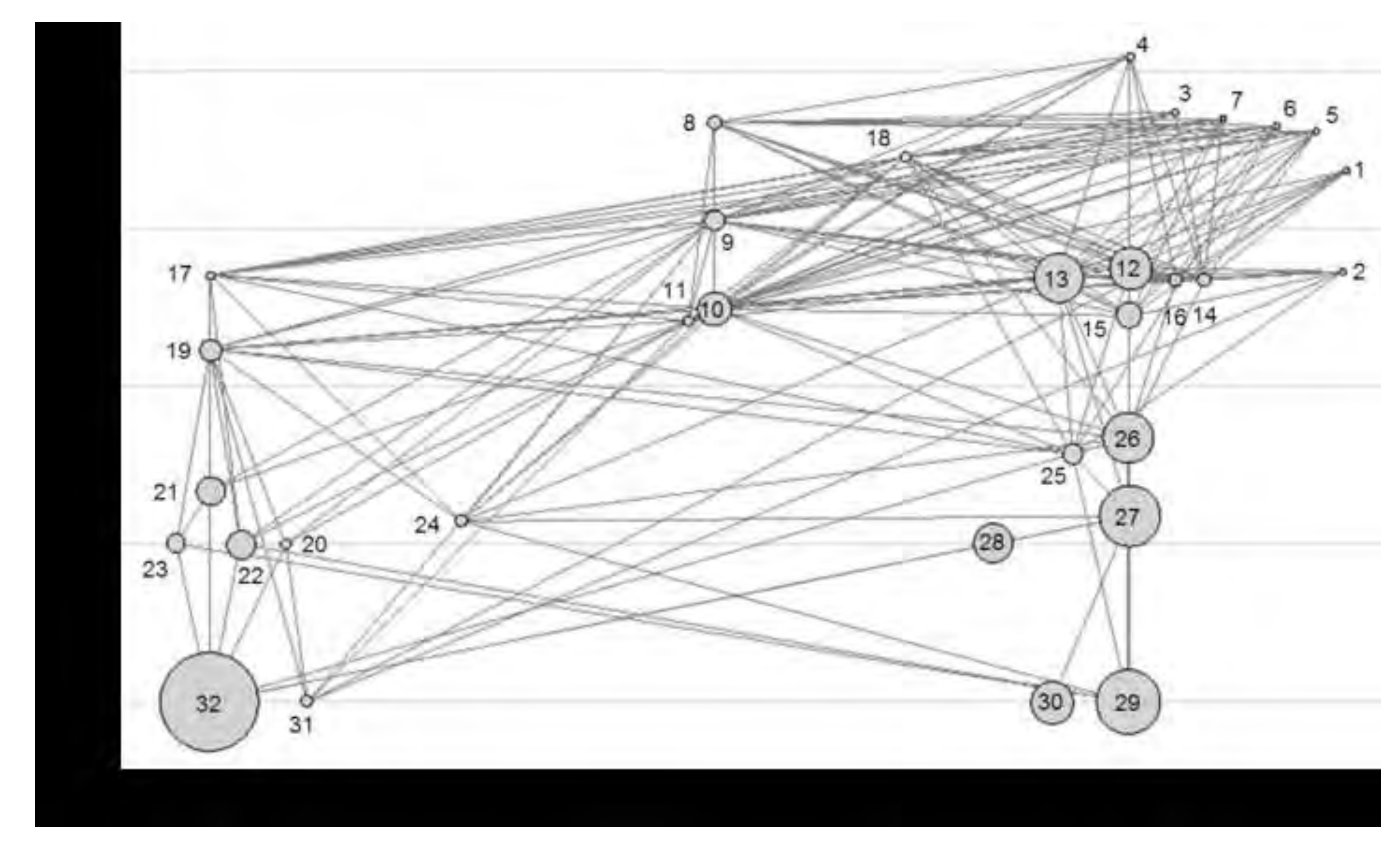

Figure_3

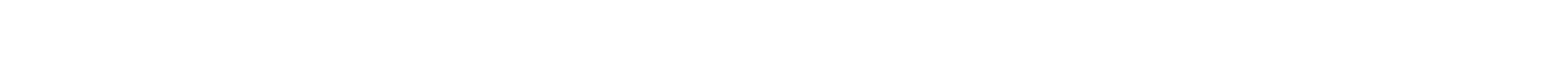

(1)

(1)

.

. 

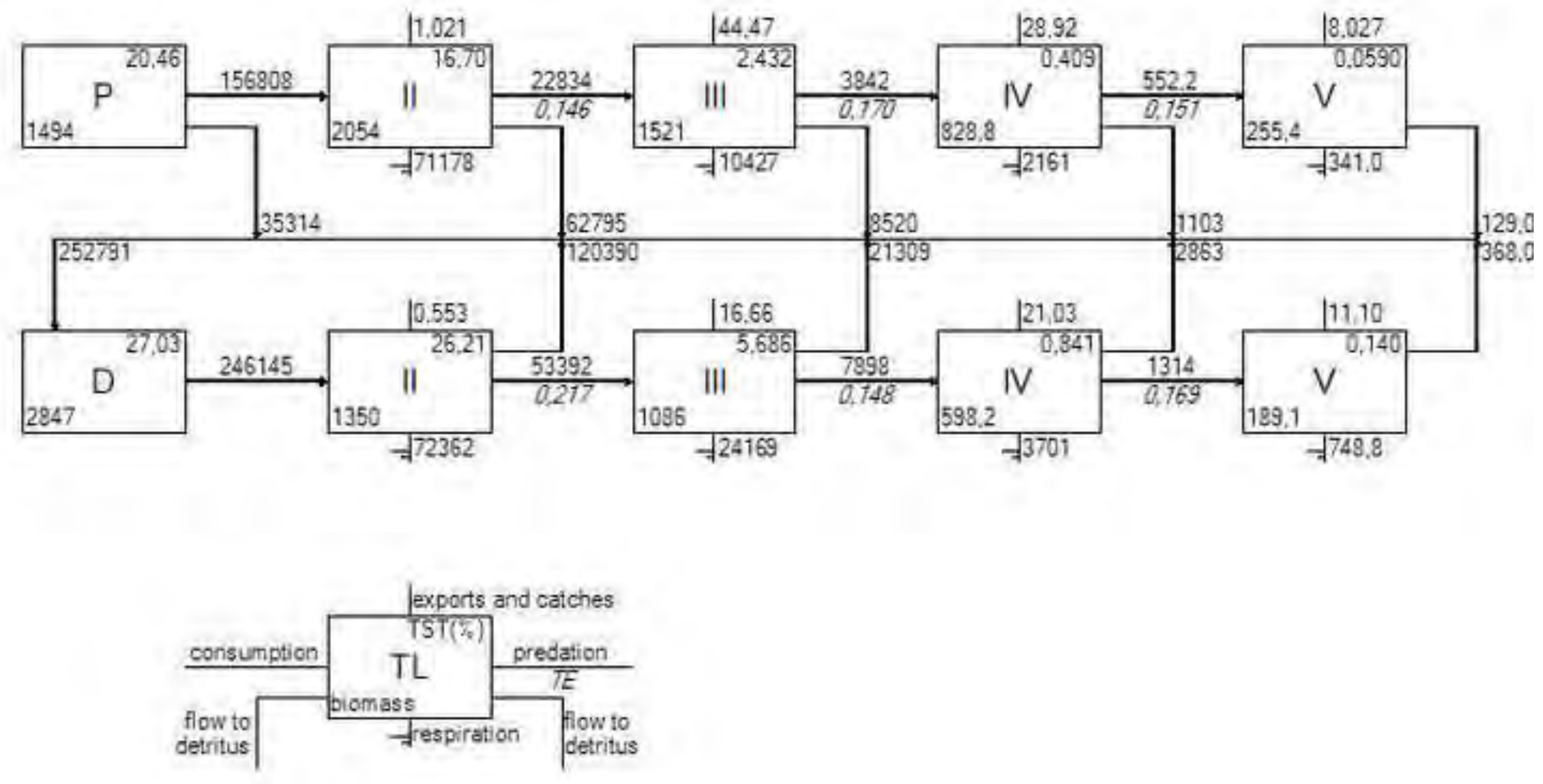


\section{Figure_5}

Click here to download high resolution image

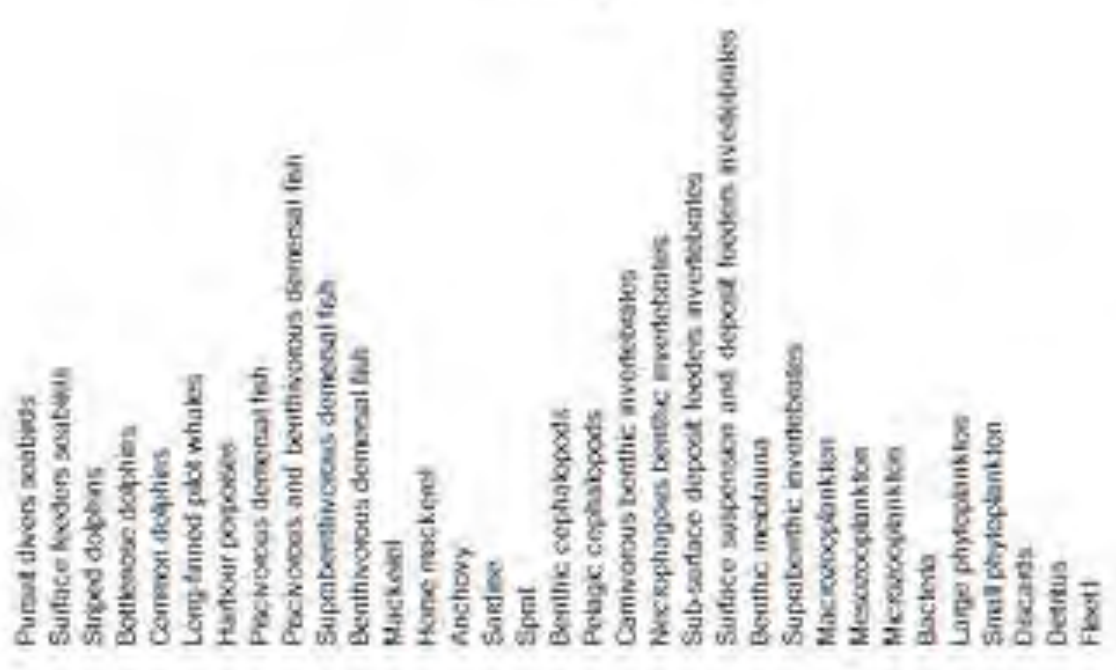

- Poetine

Q Nogative

Purtul divest seabide

Sudace leedess seabide

Seped dobhins

Bottienobe doiptents

Common dobhen

Longfinred ollot whiles

Hoptic poposes:

Placivons demersal fien

Fiponopus and berthworous demersal fin

Supraberthivereus demess heh

Berthworou demeral figh

Hockerel

Hocre mackens

Anchow

Sarene

Sprot

Berthic cephelogodt

Pelage cephalopoda

Carnorous berthic invertebres

liecroptragous berthic inverebretes

Subsulace deposit feeders invotebrates

Sulace buspersion and beopst feeders mivecobralse

Bertitic modfauny

Suprebertinc invertebrates

Macroroectarikton

Mesozooplarkdon

Mervatsoliantion

Bactera

Large phytoplanktion

Snisl ehyloptorkian

Deacards

Detitus.

Plest

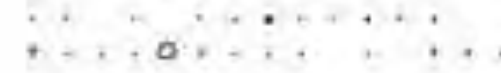

. 
